\title{
2
}

\section{The Turkish Economy and the European Economies in Transition*}

\author{
S. Togan
}

Since 1990 major changes have affected the future of the European Union (EU). At that time the future of the EU seemed set: a gradual deepening towards economic and monetary union. The collapse of communism radically shifted the challenge from deepening to widening. First to come were the EFTA countries. Since January 1995 Austria, Finland and Sweden have been members of the EU and the remaining EFTA countries, except Switzerland, have close ties with the EU through the Agreement on the European Economic Area. Then we have the potential applicants: the Czech Republic, Hungary, Poland, the Slovak Republic and Slovenia. These countries have laid a solid claim to membership. All have signed association agreements with the EU, called the Europe Agreements (EAs), but no timetable for membership has been set. The next group of potential applicants consists of Bulgaria and Romania. These countries, which have also signed EAs with the EU, are required to embark on reforms that will render them viable candidates. The fourth group of countries consists of the Baltic countries: Estonia, Latvia and Lithuania. They signed EAs during 1995. Finally we have the Mediterranean applicants: Cyprus and Turkey.

The purpose of this chapter is to study comparatively the Central and Eastern European (CEE), Baltic and Turkish economies and analyse the implications of enlargement of the EU to include these countries. Section 2.1 compares these economies, with an emphasis on foreign trade. Section 2.2 is devoted to the study of the Turkey-EU Customs Union Decision (CUD) and the EAs, and Section 2.3 considers the potential for trade between the EU, the CEE and Baltic countries and Turkey. Section 2.4 discusses these countries' chances of EU membership.

\subsection{Comparison of the Central and Eastern European, Baltic and Turkish economies}

The EU, CEE, Baltic and Turkish economies are different beings. The EU countries have developed economies. Turkey is a middle-income, free-market economy with a relatively large public sector. On the other hand, since 1989 


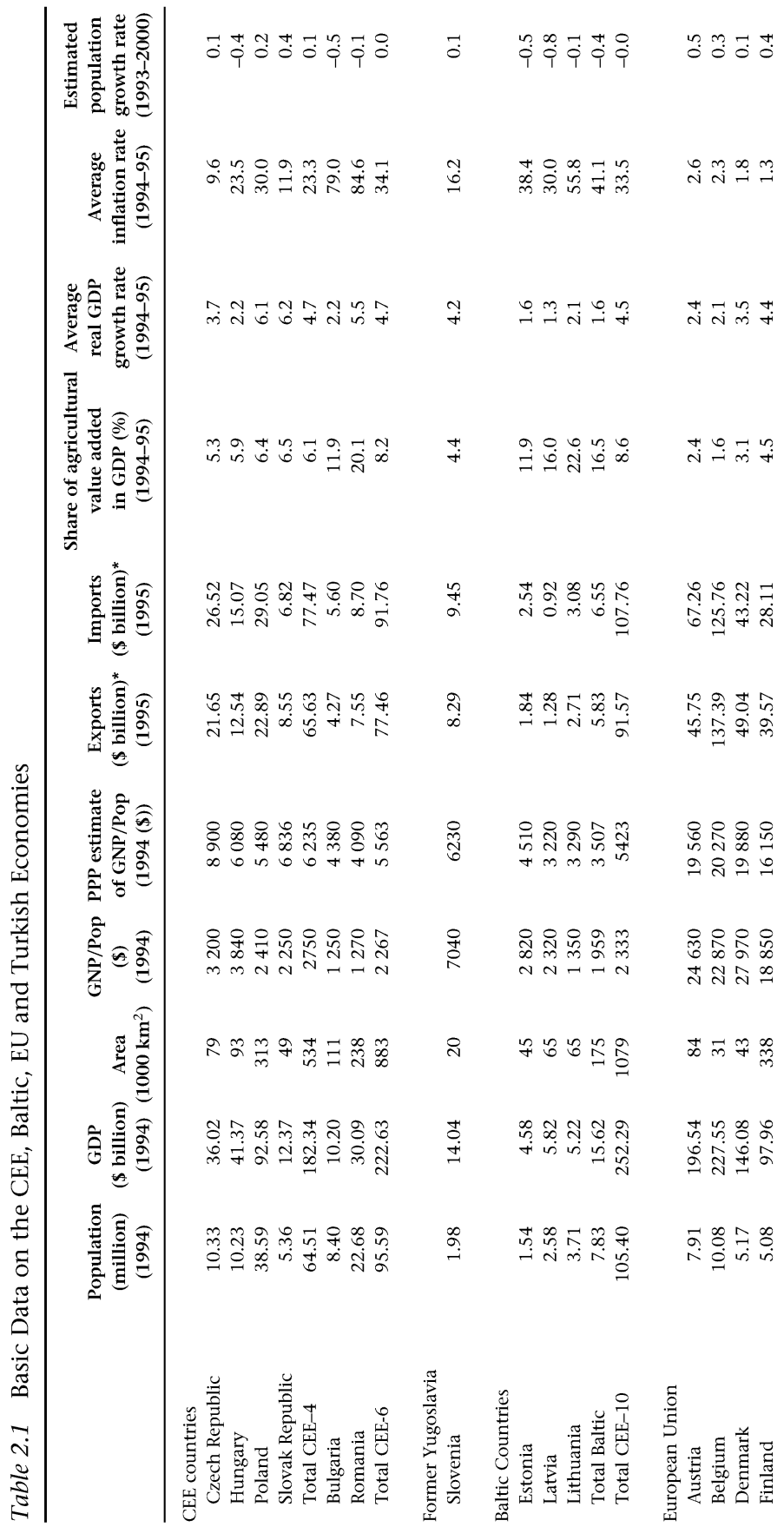




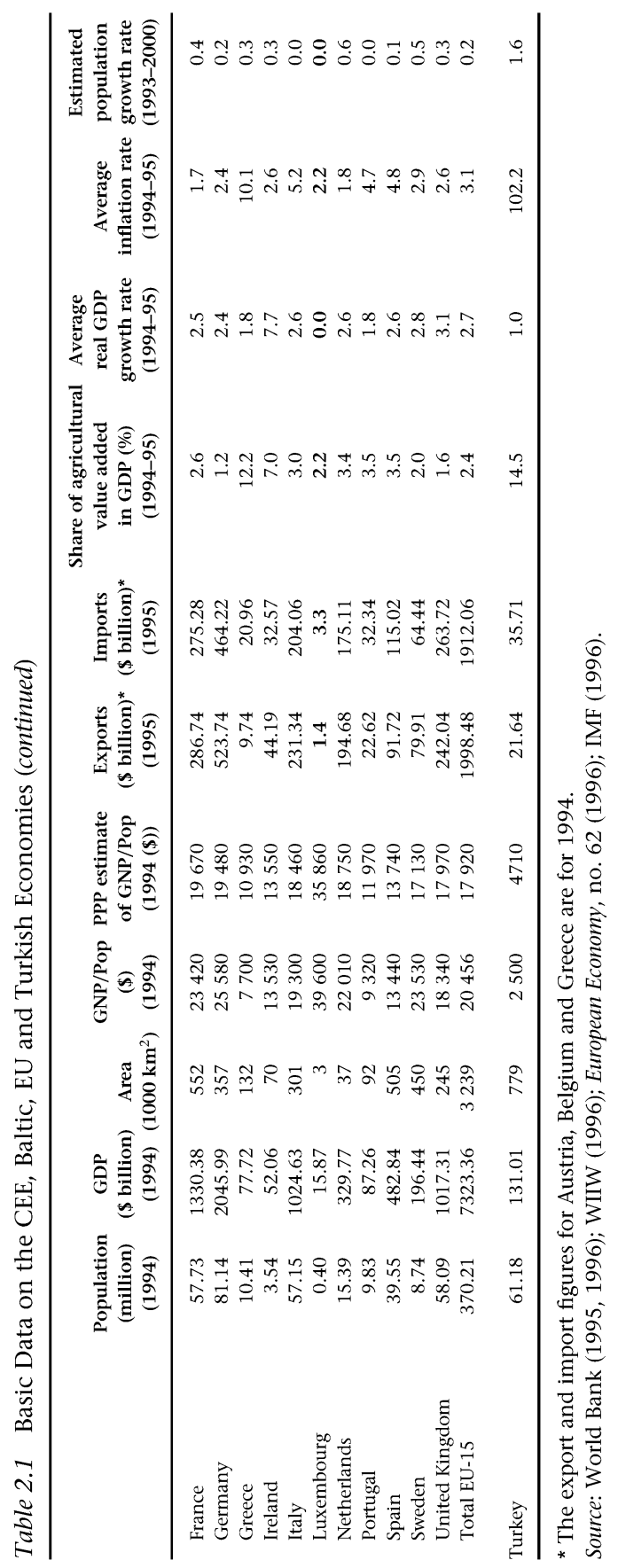


the CEE and Baltic countries have been in the process of transforming themselves from centrally planned to free-market economies and are facing all the difficulties of transition and adjustment.

Table 2.1 provides basic data on the economies under consideration for 1994-95. The per capita GNP figures reveal that of the countries considered Bulgaria was the poorest, preceded by Romania, Lithuania, the Slovak Republic, Latvia, Poland, Turkey, Estonia, the Czech Republic, Hungary and Slovenia. Turkey's per capita income lay between those of Poland and Estonia and was higher than those of Poland, Latvia, the Slovak Republic, Lithuania, Romania and Bulgaria. However in terms of purchasing power parity (PPP) the poorest country was Latvia, preceded by Lithuania, Romania, Bulgaria, Estonia, Turkey, Poland, Hungary, Slovenia, the Slovak Republic and the Czech Republic. According to the PPP figures the richest country in the group at that time was Czech Republic, and Turkey lay between Poland and Estonia. Turkey's PPP per capita income was higher than those of Estonia, Bulgaria, Romania, Lithuania and Latvia. During 1994 the combined GDP of CEE and Baltic countries amounted to 3.4 per cent of the GDP of the EU. These countries occupy a total land area of 1.08 million square kilometres and have a combined population of 105.4 million during 1994. On the other hand the GDP of Turkey amounted to 1.8 per cent of GDP of the EU. Turkey occupies a total land area of 0.78 million square kilometres and had a population of 61.2 million during 1994. Consideration of foreign trade data shows that in 1995 the exports (imports) of the CEE countries amounted to $\$ 77.46$ (\$91.76) billion, and those of Turkey to $\$ 21.64$ (\$35.71) billion. In Lithuania and Romania agriculture accounted for 22.6 per cent and 20.1 per cent of GDP respectively. The share of agriculture in Turkish GDP was 14.5 per cent, in Latvia 16 per cent, in Greece 12.2 per cent , in Estonia 11.9 per cent and in Bulgaria 11.9 per cent. In all the remaining countries the share of agriculture was less than 7 per cent, equal to the share of agriculture in Ireland. After the implementation of the marketoriented economic reforms, output in the region declined sharply. Subsequently output stabilised. In 1994-95 output increased in all of the transitional economies. In the countries under consideration, in 1994 inflation did not exceed two digits. In 1995 inflation was 9.1 per cent in the Czech Republic, 28.2 per cent in Hungary and 27.8 per cent in Poland. Finally, it should be noted that the population growth rate in all the countries under consideration has been relatively low except in Turkey.

Since the start of the transition process all the CEE and Baltic countries have made substantial progress in structural reform. In particular, prices in these countries are now largely market determined. Privatisation has proceeded rapidly, except in Bulgaria and Slovenia. In the Czech Republic the share of the private sector in GDP increased from 3 per cent in 1989 to 75 per cent in 1996 (EBRD, 1996). On the other hand the share in Bulgaria increased from 3 per cent in 1989 to 45 per cent in 1996 . By 1996 in most of the countries more than half of GDP was generated by the private sector. In comparison one should note that the share of state-owned enterprises in total value added in 
the Turkish economy amounted to 10.6 per cent in 1990 (OECD, 1992). The countries in transition still have to achieve macroeconomic stability, reduce economic distortions and free resources for productive activity. They will then be able to achieve sustainable economic growth. In the meantime policy makers have to make the economies responsive to market forces by fostering competition. It is a recognised that international trade is the most effective means of instilling competition in the economy.

Table 2.2 shows the composition of trade in the CEE and Baltic countries and Turkey during the years 1988 and 1995. From the table we note the following. The EU enormously increased its share of foreign trade with all the CEE and Baltic countries and Turkey during the period 1988-95. The share of the EU-15 in Czech exports (imports) increased from 29.84 (33.3) per cent in 1988 to 46.39 (53.91) per cent in 1995 for the Czech Republic and to 42.08 (65.02) per cent for the Slovak Republic. In the case of Poland, the EU share increased from 35.85 (33.89) per cent in 1988 to 70.06 (64.65) per cent in 1995, while in Turkey the percentage rose from 45.66 (42.88) per cent in 1988 to 51.20 (47.22) per cent in 1995.

The main EU trading partner of the CEE and Baltic countries is Germany. The German share in Czech exports (imports) increased from 15.11 (17.7) per cent in 1988 to 28.16 (17.01) per cent in 1995. In the same period in Poland the German share increased from 12.89 (13.0) per cent to 38.35 (26.63) per cent and in Bulgaria from 5.63 (16.75) per cent to 11.91 (18.28) per cent. In the case of Turkey, Germany increased its share from 18.28 (14.3) per cent in 1988 to 23.28 (15.54) per cent in 1994. The main trading partners among the new EU members are Austria and Finland. The share of Austria in Hungarian exports (imports) increased from 5.7 (7.2) per cent in 1988 to 10.39 (11.04) per cent in 1995.

Trade among the CEE countries in general decreased during the period in question. The share of exports to (imports from) the CEE and Baltic countries fell in the case of Poland from 11.6 (12.0) per cent in 1988 to 6.94 (6.38) per cent in 1995. Trade between these countries and the former Soviet Union decreased substantially. For example the share of former Soviet Union in Polish exports decreased from 24.3 (28.2) per cent to to 10.21 (9.3) per cent. From the point of view of Turkey, the most important trading partner is the EU, which accounted for 51.2 per cent of all exports and 47.22 per cent of all imports during 1995. Within the EU, Turkey's most important trading partner is - as in the case of the CEE and Baltic countries - Germany. Turkish exports accounted for 2.38 per cent of Romanian and 3.59 per cent of Bulgarian imports during 1995, while Turkey's share in Romanian and Bulgarian exports was 4.52 per cent and 8.54 per cent respectively.

Using two-digit SITC foreign trade data supplied by the Statistical Office of the European Commission, Table 2.3 aggregates commodities into 16 groups. As can be seen, textiles and clothing are important export items from Turkey and the transition countries to the EU. During 1995 their share amounted to 48.27 per cent in Turkey, 31.56 per cent in Romania, 17.82 per cent in 


\begin{tabular}{|c|c|c|c|c|}
\hline s. & 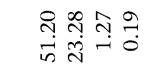 & 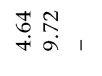 & 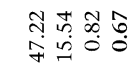 & 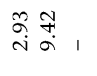 \\
\hline 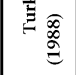 & 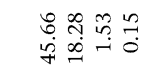 & 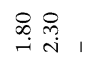 & 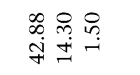 & 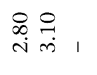 \\
\hline 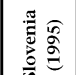 & 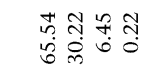 & 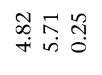 & 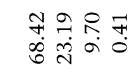 & 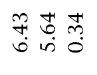 \\
\hline 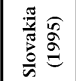 & 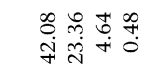 & 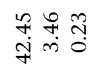 & 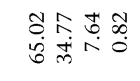 & 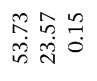 \\
\hline 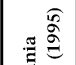 & 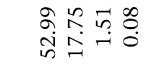 & 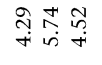 & 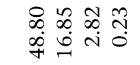 & 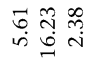 \\
\hline 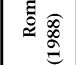 & 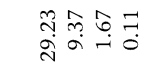 & 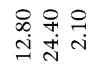 & 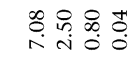 & 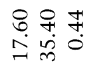 \\
\hline & 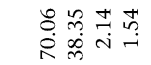 & 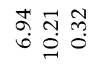 & 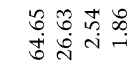 & mo \\
\hline 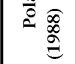 & 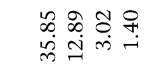 & 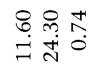 & 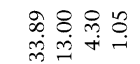 & 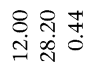 \\
\hline 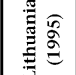 & 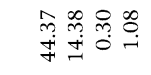 & 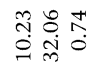 & 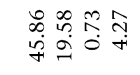 & 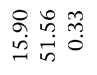 \\
\hline 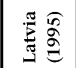 & 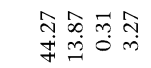 & 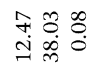 & 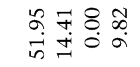 & 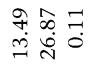 \\
\hline$e^{\stackrel{0}{\circ}}$ & 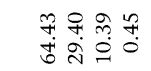 & 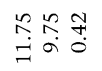 & 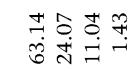 & $\begin{array}{l}\stackrel{m}{\stackrel{n}{ \pm}} \vec{m} \\
\infty\end{array}$ \\
\hline 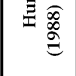 & 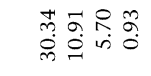 & 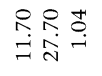 & 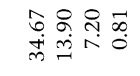 & 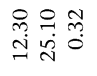 \\
\hline 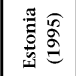 & 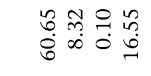 & 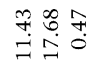 & $\begin{array}{c}\hat{\sigma} \\
\vec{b} \\
\sigma\end{array}$ & 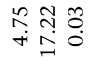 \\
\hline 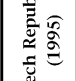 & 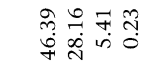 & 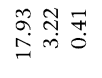 & 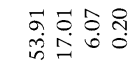 & 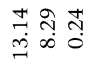 \\
\hline 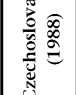 & 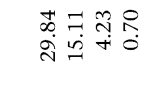 & 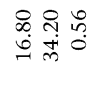 & 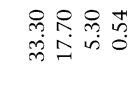 & 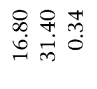 \\
\hline 월 & 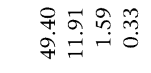 & 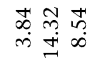 & 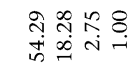 & 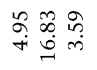 \\
\hline 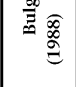 & 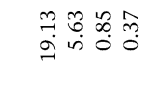 & $\stackrel{ }{\vec{m}} \stackrel{f}{\leftrightarrows}$ & 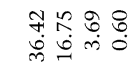 & $\underset{m}{m} \stackrel{n}{\tilde{b}}$ \\
\hline & 题 & 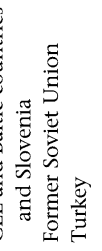 & 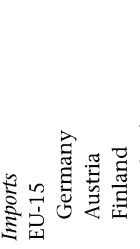 & 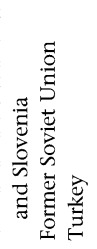 \\
\hline
\end{tabular}




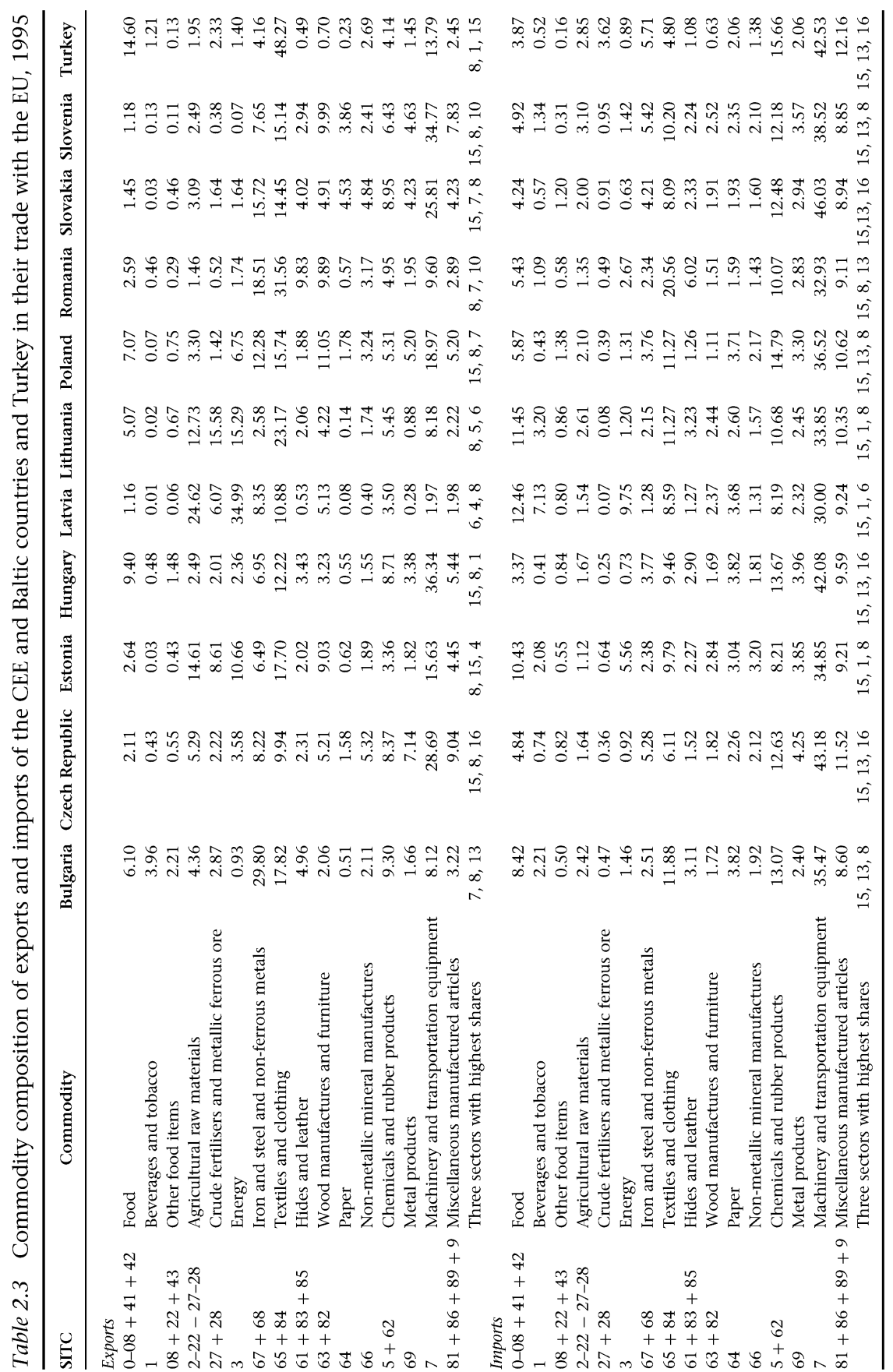


Bulgaria, 15.14 per cent in Slovenia and 14.45 per cent in the Slovak Republic. The share of machinery and transport equipment in total exports to the EU amounted to 36.34 per cent in Hungary, 28.69 per cent in the Czech Republic and 25.81 per cent in the Slovak Republic. The share of food exports to the EU amounted to 14.6 per cent in Turkey, 9.40 per cent in Hungary and 7.07 per cent in Poland, while the share of iron and steel was 29.8 per cent in Bulgaria, 15.72 per cent in the Slovak Republic and 12.28 per cent in Poland. For Turkey the most important export items were textiles and clothing, accounting for 48.27 per cent of exports to the EU during 1995. Other items of importance were food and machinery and transport equipment, accounting for 14.6 per cent and 13.79 per cent of all exports to the EU during 1995 respectively.

The lower part of Table 2.3 shows the commodity composition of imports from the EU. Machinery and transport equipment, chemicals and rubber products, and textiles and clothing are important import items in the countries under consideration. In 1995 the share of textiles and clothing in total imports from the EU amounted to 20.56 per cent in Romania, 11.27 per cent in Poland and 10.2 per cent in Slovenia. Food accounted for 10.43 per cent of Estonian, 12.46 per cent of Latvian and $\mathbf{1 1 . 4 5}$ per cent of Lithuanian imports from the EU. In the case of Turkey the most important import items from the EU were machinery and transport equipment, and chemicals and rubber products.

Table 2.4 shows the similarity index numbers for Turkish exports and imports and those of the countries in transition. Making $X_{i}^{j}$ the $j$ th country's export of commodity $i, X^{i}$ the total exports of country $j, M_{i}^{i}$ the $j$ th country's import of commodity $i, M^{i}$ the total imports of country $j, x_{i}^{j}=\left(X_{i}^{j} / X^{j}\right)$ the share of commodity $i$ in country $j^{\prime}$ s total exports, $m_{i}^{j}=\left(M_{i}^{j} / M^{j}\right)$ the share of commodity $i$ in country $j^{\prime}$ s total imports, $x^{j}=\left(x_{1}^{j}, \ldots, x_{n}^{j}\right)$ country $j^{\prime}$ 's export share vector, and $m^{j}=\left(m_{1}^{j}, \ldots, m_{n}^{j}\right)$ country $j^{\prime}$ s import share vector we compare trade vector $x$ with trade vector $m$ by using the formula for the cosine between two vectors:

$$
\alpha=\frac{\sum x_{i}^{j} m_{i}^{j}}{\sqrt{\sum x_{i}^{2} \sum m_{i}^{2}}}
$$

As long as the two vectors are exactly the same the coefficient of conformity will equal unity. Conversely, if for each commodity exported the import of the commodity equals zero, and for each commodity imported the export of the commodity equals zero, then the vectors are said to be orthogonal and the value of the coefficient of conformity equals zero. Table 2.4 shows that:

- Turkish exports to the EU are similar to the Romanian, Polish, Lithuanian, Bulgarian and Hungarian exports to the EU.

- Turkish exports to the EU are different from the CEE and Baltic countries' imports from the EU.

- Turkish imports from the EU are similar to the exports from the Czech 
Table 2.4 Indexes of similarity for Turkish exports to and imports from the EU and the CEE and Baltic countries' trade with the EU, 1995*

\begin{tabular}{lcc}
\hline & Turkish exports & Turkish imports \\
\hline Bulgaria & & \\
Exports & 0.6196 & 0.3460 \\
Imports & 0.3903 & 0.8125 \\
Czech Republic & & \\
Exports & 0.4506 & 0.7223 \\
Imports & 0.2903 & 0.8588 \\
Estonia & & \\
Exports & 0.5676 & 0.3296 \\
Imports & 0.3926 & 0.7308 \\
Hungary & 0.5889 & 0.5780 \\
Exports & 0.3492 & 0.8394 \\
Imports & 0.2237 & 0.1489 \\
Latvia & 0.3407 & 0.6697 \\
Exports & & \\
Imports & 0.6328 & 0.2743 \\
Lithuania & 0.3883 & 0.8177 \\
Exports & & 0.4721 \\
Imports & 0.7061 & 0.8586 \\
Poland & 0.3300 & 0.2365 \\
Exports & & 0.7376 \\
Imports & 0.8247 & 0.6333 \\
Romania & 0.4278 & \\
Exports & 0.5595 & \\
Imports & 0.2877 & \\
Slovakia & & \\
Exports & 0.5681 & \\
Imports & & \\
Slovenia & & \\
Imports & & \\
\hline
\end{tabular}

${ }^{*}$ Level of aggregation: 2-digit SITC.

Republic to the EU. There is only a small resemblance between Turkish imports from the EU and the exports of Latvia, Romania and Lithuania.

- Turkish imports from the EU are similar to the CEE and Baltic countries' imports from the EU.

To analyse the sectors in which the countries have comparative advantage, we consider the index values of revealed comparative advantage (RCA), calculated as:

$$
R C A_{i}=\ln \left(\frac{\left(X_{i} / X\right)}{\left(X_{i}^{e u} / X^{e u}\right)}\right)
$$


where $X_{i}$ denotes the export of commodity $i$ by the country considered, $X$ the total exports of the country considered, $X^{e u}{ }_{i}$ the total imports of commodity $i$ by the EU, excluding the exports of commodity $i$ from the country under consideration, and $X^{e u}$ the total imports of the EU, excluding the total exports of the country considered. The equation considers the share of commodity $i$ in total exports of the country relative to the share of commodity $i$ by the EU, excluding the EU imports of commodity $i$ from the country under consideration, to total EU imports, excluding again the imports of the EU from the country considered. In general, if this ratio is greater than one the natural logarithm of the variable will be positive. In that case the country is said to have comparative advantage in producing that product relative to the EU. Using the index of revealed comparative advantage, it is possible to determine in which product categories each of the CEE and Baltic countries and Turkey have the greatest comparative advantage. Table 2.5 shows the 15 two-digit SITC divisions (see the Appendix 6.2) with the highest RCA values in 1995. As such these can be considered as sectors with comparative advantage. Table 2.5 reveals the following.

The Czech Republic has comparative advantage in the production of coal (SITC 32), cork and wood (SITC 24) and sanitary, plumbing, heating (SITC 81); Hungary in the production of power generating machinery and equipment (SITC 71), live animals chiefly for food (SITC 00) and meat and meat preparations (SITC 01); Poland in coal (SITC 32), furniture (SITC 82) and cork and wood manufactures (SITC 63); Bulgaria in non-ferrous metals (SITC 68), iron and steel (SITC 67) and oil seeds and oleaginous fruit (SITC 22); Romania in footwear (SITC 85), furniture (SITC 82) and clothing (SITC 84); and Turkey in clothing (SITC 84), vegetables and fruit (SITC 5) and crude fertilisers and crude minerals (SITC 27). A comparison of the sectors in which the CEE and Baltic countries have comparative advantage with those in which Turkey has comparative advantage reveals that the Czech Republic and Turkey have comparative advantage in the production of sanitary, plumbing, heating (SITC 81), iron and steel (SITC 67) and rubber manufactures (SITC 62); Hungary and Turkey in clothing (SITC 84), sanitary, plumbing and heating (SITC 81) and crude animal and vegetable materials (SITC 29); Poland and Turkey in clothing (SITC 84) and sanitary, plumbing, heating (SITC 81); Bulgaria and Turkey in iron and steel (SITC 67), clothing (SITC 84) and travel goods (SITC 83); and Romania and Turkey in clothing (SITC 84), iron and steel (SITC 67) and non-metallic mineral manufactures (SITC 66).

Table 2.6 shows the winning sectors in each of the countries under consideration. The table is based on the order achieved from the ratio of the share of the commodity in the country's total exports in 1995 to its share of exports in 1989. As such the numbers indicate by how much the shares increased over the years. From the table it follows that the winning sectors for Turkey are fixed vegetable oils (SITC 42) and other transport equipment (SITC 79), for Hungary power generating machinery (SITC 71) and office 


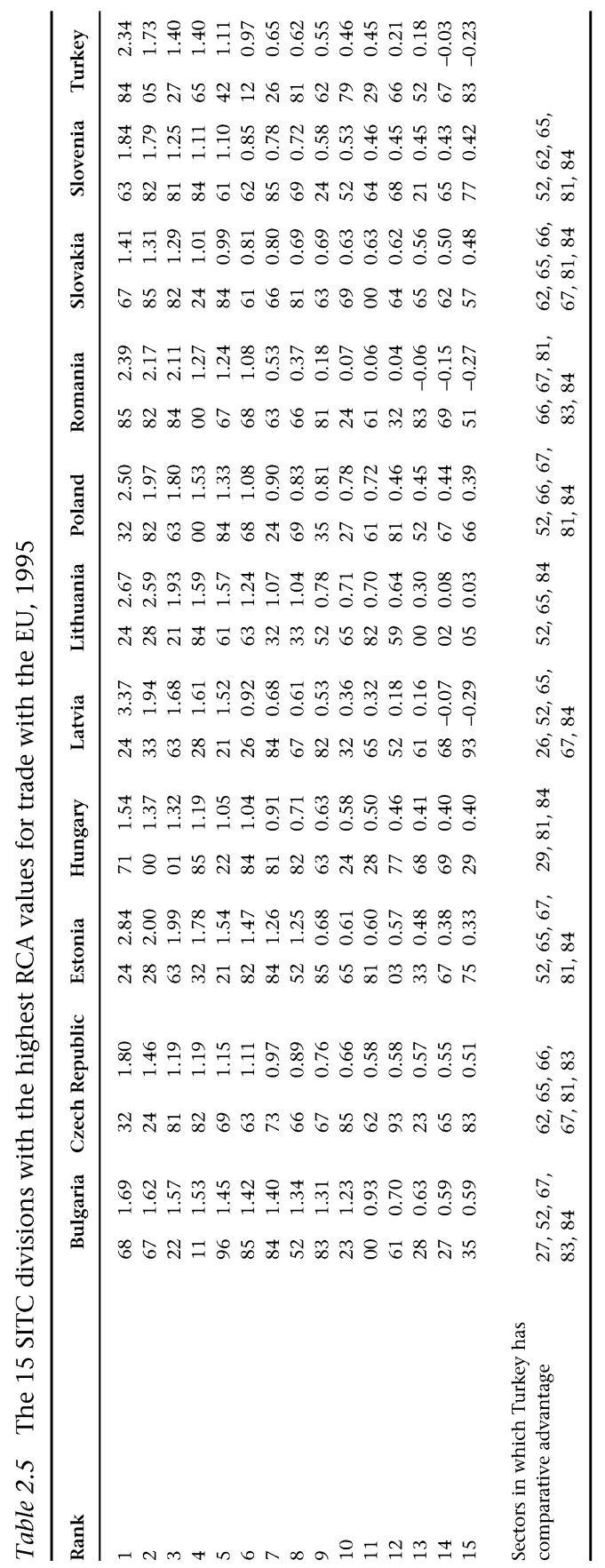




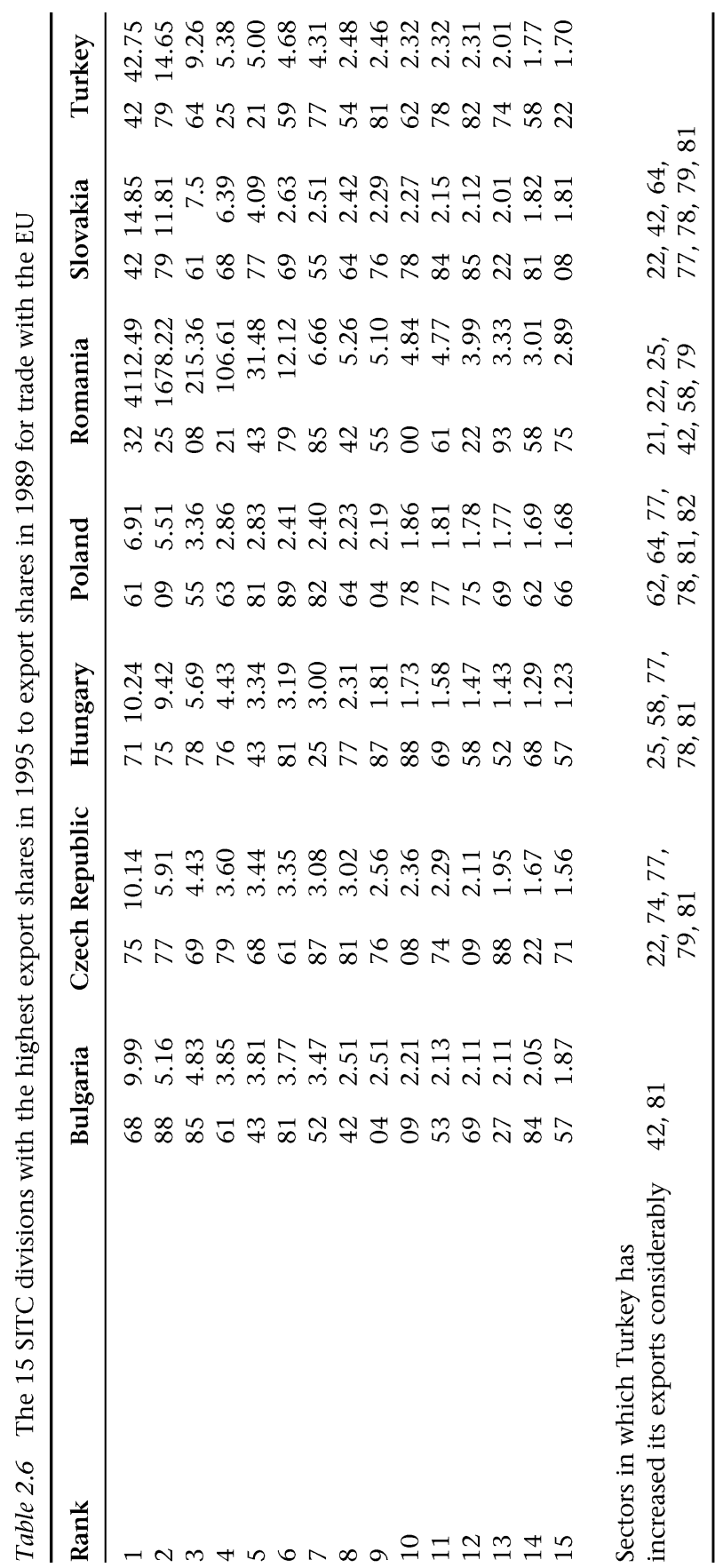




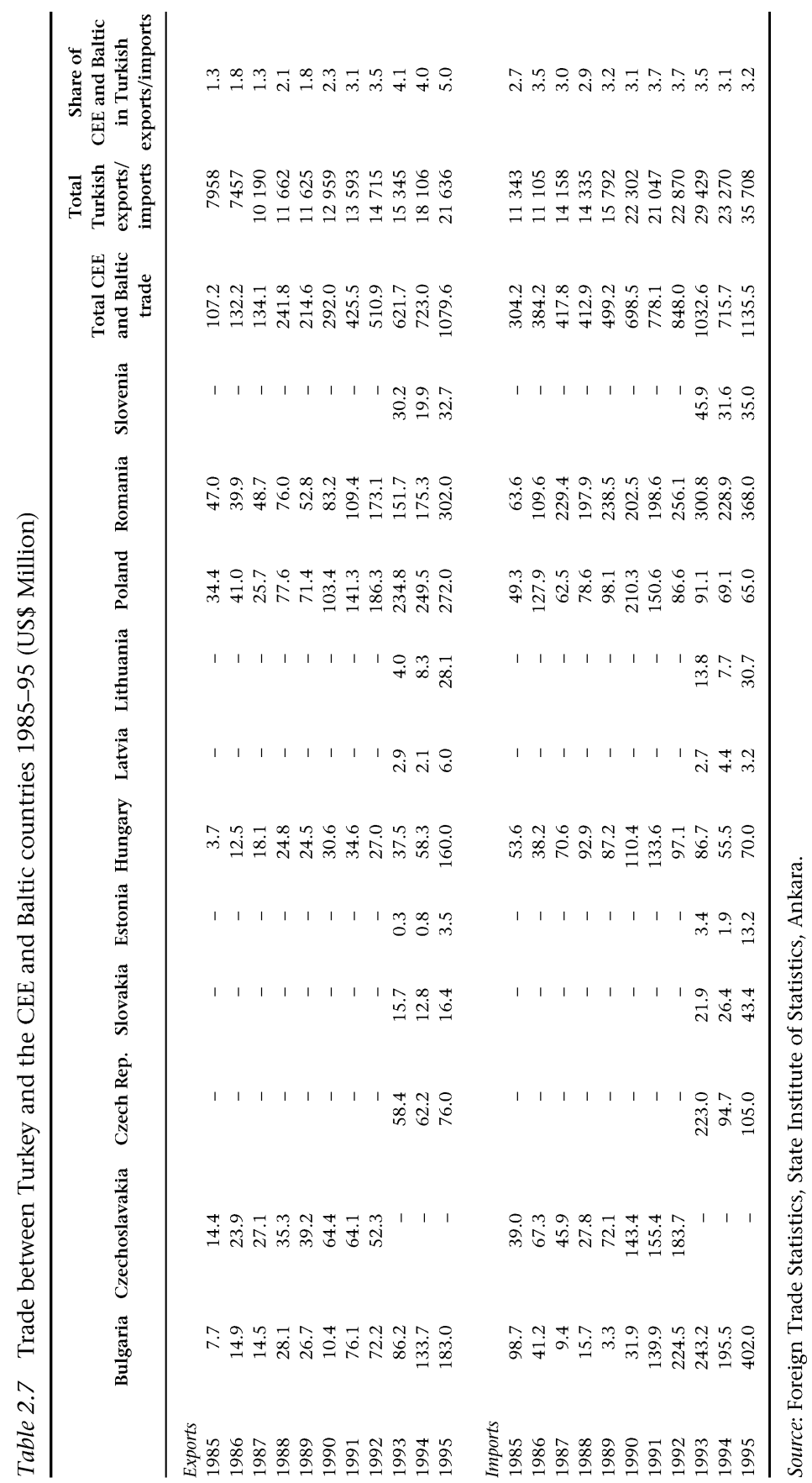


machines (SITC 75), and for Bulgaria non-ferrous metals (SITC 68) and photographic apparatus and optical goods (SITC 88). Together, Tables 2.5 and 2.6 show that Turkey will face increased competition from the transition countries in the exportation of these products to the EU.

Table 2.7 shows the trade relations between the CEE and Baltic countries and Turkey over the period 1985-95. Turkish exports to these countries increased from $\$ 107.2$ million in 1985 to $\$ 1.08$ billion in 1995 . But trade is still minuscule. By 1995 the share of exports to these countries in total Turkish exports was only 5 per cent. Similarly Turkish imports from the CEE and Baltic countries increased from 304.2 million in 1985 to 1.14 billion in 1995, a rise from 2.7 per cent to 3.2 per cent of total imports. Table 2.8 gives the commodity composition of trade between these countries and Turkey during 1995.

In 1995 the main export items from Turkey to Poland were textiles and clothing, hides and leather, and chemicals and rubber products. These commodities accounted for 88.82 per cent of all exports to Poland. Conversely, Turkey's main import items from Poland were machinery and transport equipment, textiles and clothing, and chemicals and rubber products. These commodities accounted for 60.97 per cent of all imports from Poland.

In the same year the main export items from Turkey to Romania were food, chemicals and rubber products, and textiles and clothing, together accounting for 67.8 per cent of total Turkish exports to Romania. Turkey's main import items from Romania were chemicals and rubber products, food, and iron and steel and non-ferrous metals, which accounted for 68.21 per cent of all imports from Romania.

The main export items from Turkey to the Czech Republic were textiles and clothing, food, and beverages and tobacco, accounting for 82.85 per cent of total Turkish exports to the Czech Republic. Turkey's main imports from the Czech Republic were machinery and transport equipment, food, and iron and steel and non-ferrous metals. These three commodities accounted for 71.6 per cent of all imports from the Czech Republic.

\subsection{Turkey-EU customs union and the Europe Agreements}

The integration of countries into the international trading system depends on the ability of these countries to expand their trade links with other countries. In this context we consider in the following the implications of the Turkey-EU Customs Union Decision (CUD) and the Europe Agreements (EAs).

\section{Turkey-EU customs union}

Turkey's application for association with the European Economic Community (EEC) was made in 1959. The application ultimately resulted in the signing of an Association Agreement in 1963. According to this agreement the association was to be implemented in three stages: a preparatory stage, a transitional stage and a final stage. During the preparatory stage the EEC 


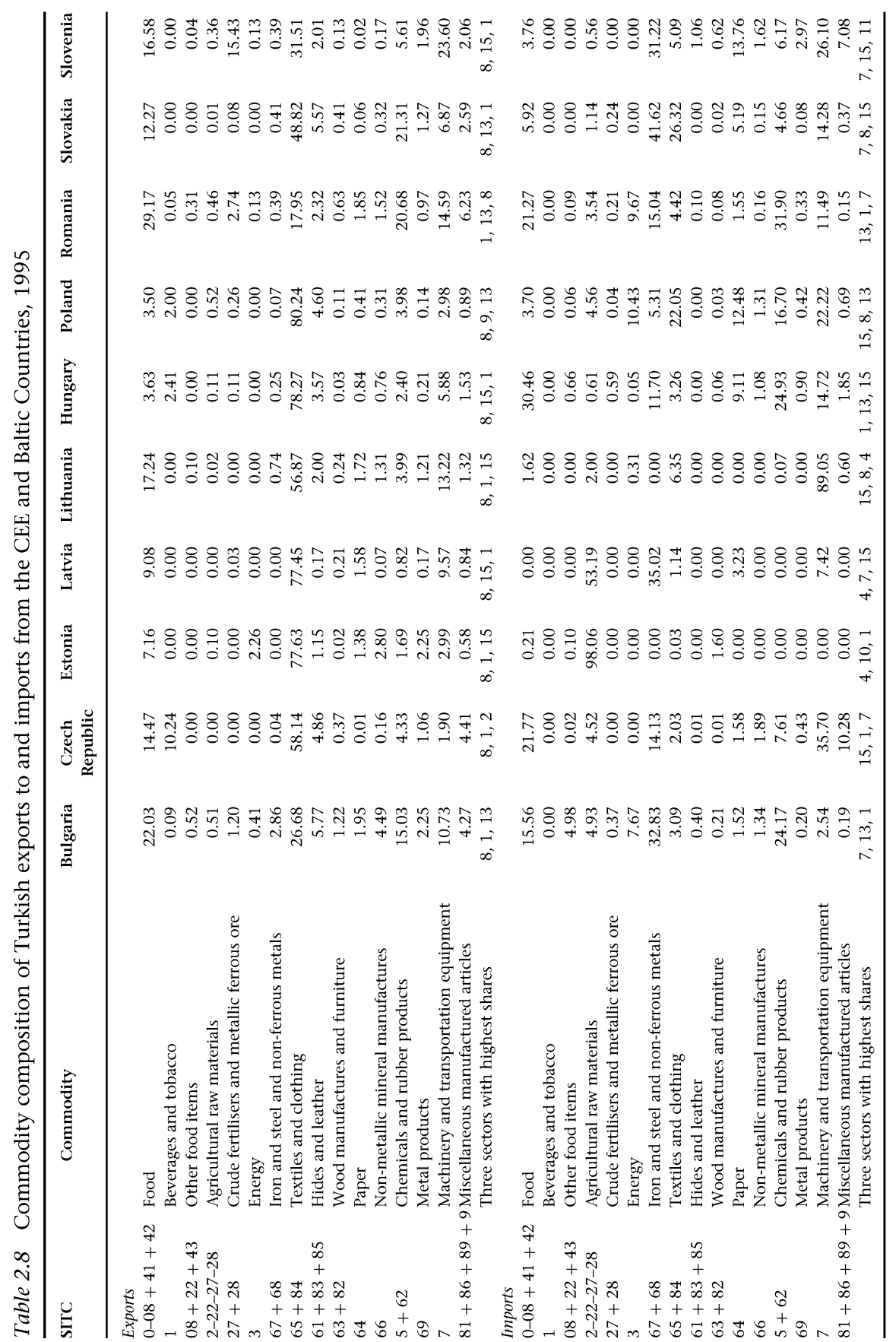


granted unilateral concessions to Turkey in the form of agricultural tariff quotas and secured financial assistance. In the meantime, Turkey was not required to change its trade regime. In 1967 Turkey lodged an application for the transitional stage. The additional protocol to the Ankara Agreement was signed in 1970 and became effective in 1973. The basic aim of the additional protocol was the establishment of a customs union (CU). In 1995 it was agreed at the Association Council meeting that a would be set up between Turkey and the EU, starting on 1 January 1996.

According to the CUD all industrial goods apart from European Coal and Steel Community (ECSC) products would circulate freely between the parties, and Turkey would impose the Community's Common Customs Tariff (CCT) on imports of industrial goods from third countries as of 1 January 1996. In the case of ECSC products, Turkey signed a free trade agreement (FTA) with the EU in July 1996, as a result of which ECSC products would receive duty free treatment between the parties in three years' time. In order to establish freedom of movement of agricultural products, Turkey has to bring its policy into line with the Common Agricultural Policy (CAP), but because of problems involved in adopting the CAP agricultural commodities remained outside the scope of the CU. Besides these changes the CUD requires that by the year 2001 Turkey should have adhered to all the preferential trade agreements the EU has concluded over time.

Table 2.9 provides estimates of nominal protection rates for 1994 (the year before the formation of the $\mathrm{CU}$ ) and 2001 (the year in which all the adjustments required by the $\mathrm{CU}$ should have been completed). In 1994 the economy-wide nominal protection rate (NPR) for trade with the EU amounted to 10.22 per cent when weighted by the sectoral import values, and the economy-wide NPR for trade with third countries was 22.14 per cent, again when weighted by sectoral import values. In 1994 the highest Turkish NPRs in trade with the EU were in fruits and vegetables (72.49 per cent), alcoholic beverages (72.1 per cent) and non-alcoholic beverages (56.92 per cent). In third countries the highest NPRs were in processed tobacco (99.91 per cent), alcoholic beverages ( 94.28 per cent) and fruits and vegetables (72.62 per cent). By the year 2001 the NPRs for industrial products should be zero in trade with the EU. We assume that the NPRs will remain unchanged at their 1994 levels for agricultural products. The calculations reported in column 2 of Table 2.9 reveal that in 38 industries the NPRs will be zero. After the formation of the customs union the average NPR in trade with the EU fell to 1.34 per cent. The highest NPRs in trade with the EU were granted to fruits and vegetables (68.01 per cent), fishery (47.84 per cent) and agriculture (41.26 per cent).

In the case of trade with third parties a distinction had to be introduced for trade with the EFTA, Mediterranean, CEE and Baltic countries, developing countries with GSP treatment and the Lomé Convention countries, with each of which the EU has concluded preferential trade agreements. Since Turkey has to apply the Community's Common Customs Tariffs and accept all the EU 


\begin{tabular}{|c|c|c|c|c|c|c|}
\hline $\begin{array}{l}\text { code } \\
\text { I-O }\end{array}$ & $\begin{array}{l}\text { NPR } \\
\text { i }\end{array}$ & $\begin{array}{l}\text { PR with EU } \\
\text { in } 1994\end{array}$ & $\begin{array}{l}\text { NPR with EU } \\
\text { after customs } \\
\text { union }\end{array}$ & $\begin{array}{l}\text { NPR with third } \\
\text { countries in } \\
1994\end{array}$ & $\begin{array}{l}\text { Average MFN } \\
\text { tariff rates } \\
\text { after customs } \\
\text { union }\end{array}$ & $\begin{array}{c}\text { Average tariff } \\
\text { rates for GSP } \\
\text { beneficiaries } \\
\text { after customs } \\
\text { union }\end{array}$ \\
\hline 1 & Agriculture & 41.27 & 41.26 & 41.65 & 41.26 & 41.26 \\
\hline 2 & Animal husbandry & 3.48 & 1.37 & 4.18 & 1.37 & 1.37 \\
\hline 3 & Forestry & 0.01 & 0.01 & 0.10 & 0.01 & 0.01 \\
\hline 4 & Fishery & 47.92 & 47.84 & 54.08 & 47.84 & 47.84 \\
\hline 5 & Coal mining & 3.33 & 0.00 & 3.33 & 4.00 & 0.00 \\
\hline 6 & Crude petroleum & 0.00 & 0.00 & 0.00 & 0.00 & 0.00 \\
\hline 7 & Iron ore mining & 0.00 & 0.00 & 2.22 & 0.00 & 0.00 \\
\hline 8 & Other metallic ore mining & 0.13 & 0.00 & 1.21 & 0.00 & 0.00 \\
\hline 9 & Non-metallic mining & 9.09 & 0.00 & 11.02 & 0.95 & 0.95 \\
\hline 10 & Stone quarying & 1.95 & 0.00 & 2.18 & 0.02 & 0.00 \\
\hline 11 & Slaughtering and meat & 10.21 & 10.21 & 10.21 & 10.21 & 10.21 \\
\hline 12 & Fruits and vegetables & 72.49 & 68.01 & 72.62 & 68.01 & 68.01 \\
\hline 13 & Vegetable and animal oil & 16.31 & 16.31 & 16.38 & 16.29 & 16.29 \\
\hline 14 & Grain mill products & 41.33 & 41.02 & 41.33 & 41.02 & 41.02 \\
\hline 15 & Sugar refining & 28.79 & 28.79 & 28.79 & 28.79 & 28.79 \\
\hline 16 & Other food processing & 26.47 & 18.31 & 28.99 & 18.31 & 18.31 \\
\hline 17 & Alcoholic beverages & 72.10 & 5.25 & 94.28 & 11.28 & 7.35 \\
\hline 18 & Non-alcoholic beverages & 56.92 & 0.00 & 69.81 & 14.83 & 0.00 \\
\hline 19 & Processed tobacco & 44.40 & 0.00 & 99.91 & 9.40 & 0.00 \\
\hline 20 & Ginning & 0.00 & 0.00 & 2.22 & 0.72 & 0.72 \\
\hline 21 & Textiles & 21.19 & 0.00 & 27.10 & 17.30 & 7.60 \\
\hline 22 & Clothing & 14.75 & 0.00 & 20.65 & 19.90 & 9.30 \\
\hline 23 & Leather and fur production & 7.85 & 0.00 & 12.57 & 10.20 & 2.80 \\
\hline 24 & Footwear & 24.40 & 0.00 & 35.70 & 22.50 & 9.10 \\
\hline 25 & Wood products & 15.25 & 0.00 & 18.97 & 2.00 & 0.05 \\
\hline 26 & Wood furniture & 26.22 & 0.00 & 32.64 & 5.50 & 0.00 \\
\hline 27 & Paper and paper products & 13.59 & 0.00 & 17.58 & 2.70 & 0.00 \\
\hline 28 & Printing and publishing & 8.23 & 0.00 & 10.79 & 4.52 & 0.00 \\
\hline 29 & Fertilisers & 8.22 & 0.00 & 16.38 & 8.10 & 0.00 \\
\hline 30 & Pharmaceutical production & 3.33 & 0.00 & 8.99 & 5.30 & 0.00 \\
\hline 31 & Other chemical production & 10.79 & 0.00 & 17.62 & 8.71 & 0.04 \\
\hline 32 & Petroleum refining & 22.54 & 0.00 & 24.35 & 2.70 & 0.00 \\
\hline 33 & Petroleum and coal products & 5.62 & 0.00 & 7.52 & 2.15 & 0.00 \\
\hline 34 & Rubber products & 19.57 & 0.00 & 23.91 & 5.60 & 0.03 \\
\hline 35 & Plastic products & 24.61 & 0.00 & 31.68 & 9.90 & 0.00 \\
\hline 36 & Glass and glass production & 16.85 & 0.00 & 21.94 & 5.76 & 0.00 \\
\hline 37 & Cement & 30.45 & 0.00 & 32.88 & 3.14 & 0.00 \\
\hline 38 & Non-metallic minerals & 18.33 & 0.00 & 23.21 & 5.47 & 0.00 \\
\hline 39 & Iron and steel & 8.00 & 0.00 & 10.70 & 5.50 & 3.30 \\
\hline 40 & Non-ferrous metals & 4.52 & 0.00 & 8.43 & 3.20 & 0.50 \\
\hline 41 & Fabricated metal products & 18.36 & 0.00 & 25.29 & 6.00 & 0.11 \\
\hline 42 & Non-electrical mechinery & 7.36 & 0.00 & 12.50 & 4.40 & 0.00 \\
\hline 43 & Agricultural machinery & 6.98 & 0.00 & 12.18 & 3.50 & 0.00 \\
\hline 44 & Electrical machinery & 9.69 & 0.00 & 16.64 & 8.30 & 0.00 \\
\hline 45 & Shipbuilding and repairing & 6.13 & 0.00 & 12.89 & 0.50 & 0.00 \\
\hline 46 & Railroad equipment & 0.00 & 0.00 & 4.61 & 4.04 & 0.00 \\
\hline 47 & Motor vehicles & 27.33 & 0.00 & 33.10 & 9.40 & 0.00 \\
\hline 48 & Other transport equipment & 0.01 & 0.00 & 1.76 & 1.60 & 0.00 \\
\hline 49 & Other manufacturing industries & 2.92 & 0.00 & 8.19 & 2.95 & 0.00 \\
\hline \multicolumn{2}{|r|}{ Mean } & 10.22 & 1.34 & 22.14 & 6.92 & 2.71 \\
\hline \multicolumn{2}{|c|}{ Standard deviation } & 17.68 & 14.48 & 15.36 & 13.79 & 14.51 \\
\hline
\end{tabular}

Sources: Author's own calculations; Laird and Yeats (1990); GATT (1993). 
preferential agreements by 2001, it will be faced with different sets of tariff rates for different groups of countries. In the case of the EFTA, CEE and Baltic countries and Israel, which have FTAs with the EU, the nominal tariff rates applied by Turkey in the year 2001 to imports from these countries will be identical to those applied to imports from the EU. Thus the NPRs shown in column 2 of Table 2.9 will apply to about 53.77 per cent of imports, which was the average share of Turkish imports from the EU, EFTA, CEE and Baltic countries and Israel in total imports during the 1991-93 period. For Israel and the CEE and Baltic countries the average Turkish tariff rates will decrease from 22.14 per cent to 1.34 per cent. On the other hand the share of developing countries with GSP treatment in Turkish imports is around 27.54 per cent. Finally the share in Turkish imports of countries such as the United States, Japan and Canada, to which the EU applies the CCT, is 18.46 per cent. Column 4 of Table 2.9 shows the average MFN tariff rates obtained under the assumption that Turkey will not have to change the NPRs on agricultural commodities, while column 5 shows, under the same assumptions, the average tariff rates for GSP beneficiaries. Thus we assume that the tariff rates Turkey will apply by 2001 will be those shown in columns 2,4 and 5 . Note that the average NPR for the EU countries and for countries with which the EU has FTAs will be 1.34 per cent, for the United States, Japan and Canada it will be 6.92 per cent and for GSP beneficiaries 2.71 per cent.

Table 2.10 shows the average share of imports from various country groups in total Turkish imports, as well as the corresponding Turkish NPRs applicable to imports from these groups before and after the formation of the CU with the EU. As can be seen, all countries have benefited from the reduction in nominal protection rates in Turkey as a result of the CU. Regarding EU market access for Turkish exports, the EU abolished the nominal tariff rates on imports of industrial goods from Turkey on 1 September 1971. However certain exceptions were made. The EU retained the right to charge import duties on some oil products over a fixed quota, and to implement a phased reduction of duties on particular textile products from Turkey. On the other hand trade

Table 2.10 Share of various country groups' imports in total Turkish imports and corresponding Turkish NPRs before and after the formation of the customs union with the EU (1991-93 averages)

\begin{tabular}{lrrr}
\hline & $\begin{array}{c}\text { Share in } \\
\text { imports }\end{array}$ & $\begin{array}{c}\text { NPR } \\
\text { 1994 }\end{array}$ & $\begin{array}{c}\text { NPR } \\
\text { 2001 }\end{array}$ \\
\hline EU countries & 46.02 & 10.22 & 1.34 \\
Countries with which the EU has FTAs & 7.75 & 22.14 & 1.34 \\
GSP countries & 27.54 & 22.14 & 2.71 \\
Countries where the EU applies MFN tariffs & 18.46 & 22.14 & 6.92 \\
Mediterranean countries & 1.60 & 22.14 & 2.71 \\
\hline
\end{tabular}

Source: Togan (1995). 
within the province of the ECSC has been protected by the EU through nontariff barriers and antidumping measures. After 2001 the NPRs applied by the EU on imports of all industrial goods from Turkey, including textile and steel products, will be reduced to zero as long as Turkey fulfils all the obligations laid down in the CUD, including measures relating to intellectual, industrial and commercial property rights, competition policy, and public aid. Furthermore Turkey has to conform to the EU's garments and textile agreements with third countries. As emphasised above, the market access conditions of the CUD will not cover agricultural commodities. Finally, in the event of non-fulfilment of Turkey's obligations by 2001 the country will be faced with antidumping and countervailing duty measures. In this case the market access restrictions will extend beyond agricultural commodities to sensitive products such as textiles, clothing and iron and steel products.

The CUD has offered rapid liberalisation of trade. However there are restrictions in the form of countervailing duties, antidumping procedures and safeguard measures (Articles 36, 42 and 61 of the CUD). Article 36 specifies that if a particular practice is incompatible with the competition rules of the CU, as specified in Articles 30-32 of the CUD, and 'in the absence of such rules if such practice causes or threatens to cause serious prejudice to the interest of the other Party or material injury to its domestic industry', the EU or Turkey may take appropriate measures. Article 42 allows antidumping action to be taken if Turkey fails to implement the competition rules of the $\mathrm{CU}$ and other relevant parts of the acquis communautaire. In such cases Article 47 of the additional protocol signed in 1970 between Turkey and the EC will remain in force. According to this article the Association Council, if it finds evidence of dumping, shall address recommendations to the persons who originated the practice. The injured party can itself take measures if the Council has taken no decision within three months and the dumping has continued. If immediate action needs to be taken the party may introduce a temporary protection measure, such as an antidumping duty, although the Council may recommend the withdrawal of such measures. Finally, Article 61 states that safeguard measures, as specified in Article 60 of the additional protocol, will remain valid. According to Article 60 the EU can introduce protective measures if serious disturbances occur in a sector of the EU economy or prejudice the financial stability of one or more member states, or if difficulties arise that adversely affect the economic situation in a region of the EU. Under the terms of the agreement Turkey is also entitled to take such measures.

The CUD is silent on three issues: the supply of services, the movement of capital and the movement of labour.

\section{The Europe Agreements}

During the 1990s the CEE and Baltic countries introduced sweeping reforms that changed the nature of their trade system and set the stage for integration 
into the world economy. The packages comprised three elements. First, the compulsory import and export licences of the period before the 1990s were abolished and with them the state monopoly on foreign trade. Second, current account convertibility of the currencies was introduced. Finally, nearly all quantitative restrictions on exports and imports were lifted. As a result the customs tariff has become the primary instrument of foreign trade policy and there have been frequent tariff adjustments.

Right after the political upheavals of the late 1980s the CEE and Baltic countries looked to the EC for support, which came in the form of trade and cooperation agreements in 1988-90. Negotiations on association agreements, called the Europe Agreements (EAs), between the EU and the CSFR, Hungary and Poland started in December 1990 and were signed on 16 December 1991. Interim agreements covering the trade aspects of the EAs entered into force on 1 March 1992. Similar agreements with Romania and Bulgaria were signed in 1993 and the interim agreements with Romania and Bulgaria took effect on 1 May 1993 and 1 February 1994 respectively. Since then all the agreements have been ratified by national parliaments and the European Parliament. EAs with the Baltic countries and Slovenia were signed in June 1995 and June 1996 respectively.

For the CEE and Baltic countries, EU association represents a tangible means of returning to the European fold. The agreements, which remain in force for an unspecified period, include (besides commercial and economic cooperation) political dialogue and cultural cooperation. The agreements are aimed at the establishment of a free trade area and are a step towards the goal of integrating the participating countries into the EU. The preamble makes this conditional on pluralistic democracy based on the rule of law, and commitment to the market economy.

All the EAs have a similar structure and contain between 122 and 124 articles. Articles 1-6 in the EA with Hungary deal with political dialogue and general principles. Articles 7-36 cover the movement of goods, and Articles 37-58 the movement of workers and the establishment and supply of services. Articles 59-69 cover movements of capital, competition and approximation of laws. Articles 70-103 refer to economic, cultural and financial cooperation. Articles 104-24 contain institutional, general and final provisions. Each EA is accompanied by a set of annexes and protocols.

According to the interim agreements the free trade area will be established at the end of a maximum transitional period of ten years, divided into two stages of five years each, starting from the entry into force of the agreements (March 1992). Thus by March 2002 the Czech Republic, Hungary, Poland, the Slovak Republic and the EU member states will constitute a free trade area. On the EU side, the association agreements consolidate all the existing unilateral trade concessions, while laying the ground for the complete removal of all obstacles to trade by the end of the transitional period. The trade provisions involve the immediate removal of all quotas on industrial commodities, apart 
from textiles and ECSC products, while import tariffs will be progressively eliminated over a period of two to five years.

The CEE and Baltic countries will reciprocate more slowly by phasing out tariffs and quotas over four to nine years. To qualify for concessions under the EA, products must originate in these countries. Mineral and agricultural products are automatically seen as fulfilling this condition, and for all other commodities the imported content of exports must not exceed 40 per cent of their value. In other words there is a 60 per cent local content requirement, which is rather strict. Finally, it should be stressed that the EAs provide for a cumulation of origin among the CEE and Baltic countries, whereby a product that is exported from one associate country to another associate country and has undergone no, or only limited, reworking or processing in the importing country is considered as originating in the importing country.

An important aspect of the agreements is access to EU markets by the countries in transition. For most products defined in the international trade classifications, the agreements offered access to the EU markets free of tariffs and quantitative restrictions $(\mathrm{QR})$ within one year. The process of trade liberalisation excludes agricultural products. In the case of agricultural products the agreements affect five main product groups: meat, live animals, fruit, vegetables and processed agricultural commodities. Trade in grain is not covered by the agreements. Agricultural exports from the CEE and Baltic countries were permitted to increase by 10 per cent a year for five years, while variable levies decreased by 30-60 per cent over a three-year period. Export quantities above the quota limits are subject to full tariffs and levies.

Kaminski (1994), when discussing the industrial commodities covered by the EAs, states that these commodities account for more than three quarters of EU imports from the transitional economies. Only Bulgaria and Hungary, which specialise in agricultural products, have relatively low shares, as shown in Table 2.11, which lists the average EU tariff rates on industrial imports from selected countries during the pre-agreement period. The average tariff rate was 0.1 per cent for Poland, a GSP beneficiary country, and 6.9 per cent for Bulgaria, a country without GSP status. Besides tariffs the CEE and Baltic countries faced non-tariff barriers (NTB), which had become the major instrument of protection in the EU. The level of vulnerability to NTBs, as measured by the share of imports subject to NTBs, varied among these countries. It was highest in Romania and lowest in Bulgaria.

Kaminski (ibid.) divides industrial commodities into six groups: the immediate free-trade group, the textiles and clothing group, the ECSC group, the quota/five-year delayed group, the one-year delayed free-trade group and the four-year delayed free-trade group. The quota/five-year delayed group which includes organic and inorganic chemicals, some leather products, cork and wood products, glass, electrical machinery, optical goods, plastics, footwear, furniture, motor vehicles and toys, is quite large in terms of CEE exports to the EU, accounting for one-fourth to one-third of EU industrial 
Table 2.11 The importance of industrial products in CEE exports to the EU and pre-agreement market access for industrial commodity groups, 1991

\begin{tabular}{|c|c|c|c|c|c|}
\hline & \multirow{2}{*}{$\begin{array}{l}\text { Share of industrial } \\
\text { commodities in } \\
\text { total exports to the EU }\end{array}$} & \multicolumn{2}{|c|}{$\begin{array}{l}\text { Simple average } \\
\text { tariff rate }\end{array}$} & \multicolumn{2}{|c|}{ NTB coverage ratio } \\
\hline & & Industrial & Other & Industrial & l Other \\
\hline Bulgaria & 73.0 & 6.9 & 11.6 & 22.5 & 48.3 \\
\hline Czechoslovakia & 92.0 & 7.0 & 11.7 & 24.0 & 52.5 \\
\hline Hungary & 73.0 & 0.1 & 9.4 & 24.2 & 57.7 \\
\hline Poland & 81.0 & 0.1 & 10.5 & 23.6 & 48.6 \\
\hline \multirow[t]{2}{*}{ Romania } & 94.0 & 0.0 & 8.6 & 28.4 & 59.8 \\
\hline & $\begin{array}{l}\text { Share in } \\
\text { industrial } \\
\text { exports }\end{array}$ & & $\begin{array}{l}\text { Simple } \\
\text { average } \\
\text { tariff } \\
\text { rate }\end{array}$ & & $\begin{array}{l}\text { NTB } \\
\text { coverage } \\
\text { ratio }\end{array}$ \\
\hline \multicolumn{6}{|c|}{ Immediate free trade group } \\
\hline Bulgaria & 43.0 & & 5.6 & & 3.6 \\
\hline Czechoslovakia & 44.0 & & 5.7 & & 3.8 \\
\hline Hungary & 50.0 & & 0.0 & & 3.7 \\
\hline Poland & 41.0 & & 0.1 & & 3.8 \\
\hline Romania & 32.0 & & 0.0 & & 3.4 \\
\hline \multicolumn{6}{|c|}{ Textiles and clothing group } \\
\hline Bulgaria & 20.9 & & 10.8 & & 90.6 \\
\hline Czechoslovakia & 13.6 & & 10.7 & & 87.6 \\
\hline Hungary & 21.4 & & 0.1 & & 85.1 \\
\hline Poland & 17.6 & & 0.0 & & 88.8 \\
\hline Romania & 28.2 & & 0.1 & & 86.2 \\
\hline \multicolumn{6}{|c|}{ The steel ECSC subgroup } \\
\hline Bulgaria & 11.4 & & 5.4 & & 74.6 \\
\hline Czechoslovakia & 10.5 & & 5.6 & & 64.4 \\
\hline Hungary & 4.2 & & 0.0 & & 58.2 \\
\hline Poland & 4.5 & & 0.1 & & 57.4 \\
\hline Romania & 3.6 & & 0.0 & & 68.2 \\
\hline \multicolumn{6}{|c|}{ The quota/five-year delayed free trade group } \\
\hline Bulgaria & 16.3 & & 8.6 & & 18.8 \\
\hline Czechoslovakia & 26.5 & & 8.7 & & 20.6 \\
\hline Hungary & 24.3 & & 0.0 & & 21.0 \\
\hline Poland & 23.6 & & 0.0 & & 21.7 \\
\hline Romania & 31.4 & & 0.0 & & 23.7 \\
\hline
\end{tabular}

Source: Kaminski (1994). 
imports. The trade-liberalising measures for this group were a mixture of cuts in customs duties and increases in tariff quotas and ceilings. Customs duties were suspended within the limits of tariff quotas, which were increased annually by about 20 per cent. Customs duties on imports in excess of quotas were reduced progressively to zero by the end of fifth year. By 1997 there were no longer any quotas or tariffs. For products within the province of the ECSC, specific provisions applied. In particular customs duties on imports applicable in the EU on steel products were completely eliminated by the beginning of the fifth year. Quantitative restrictions on iron and steel products were eliminated with the entry into force of the interim agreements. In the case of coal products, the time required for liberalisation of trade was four years and the EU abolished quantitative restrictions in one year. Certain product imports were liberalised by Spain and Germany within four years. Kaminski (ibid.) estimates that in the case of the steel ECSC subgroup the MFN tariffs were in the range of 5.4-5.6 per cent and the GSP tariffs $0.1-0.0$ per cent. The NTB coverage ratios varied between 57.4 per cent and 74.6 per cent. In 1991 the share of this group in industrial exports was 11.4 per cent in the case of Bulgaria and 3.6 per cent for Romania.

The EU import duties on textiles and clothing were removed over five years and immediately in the case of outward processing trade. Quantitative restrictions were removed after five years. Finally, in accordance with the asymmetry principle, customs duties on most industrial products originating in the EU were progressively reduced to zero. The time schedule for Poland was five years and for the Czech Republic, Hungary and the Slovak Republic nine years.

The above considerations show that by the end of the twentieth century the NTB coverage ratios, the average tariff rates and their standard deviation were reduced to zero for all groups of industrial CEE and Baltic exports to the EU. Similarly, in the case of EU industrial exports to these countries the NTB coverage ratios, the average tariff rates and their standard deviation will be reduced to zero by the year 2002. Thus, the EAs have led to the rapid liberalisation of trade. However, as in the case of the Turkey-EU CUD, there are restrictions in the form of anti-dumping procedures, countervailing duties and safeguard measures, as laid down in Articles 29-31, 33 and 62-4 of the EAs. Article 29 allows anti-dumping actions to be taken, and any party faced with dumping may act in accordance with Article VI of the GATT. The Association Council has to be informed of a dumping case as soon as the importing party starts its investigation. If no solution has been reached within 30 days, the importing party may take appropriate measures.

It is well known that the EU anti-dumping procedures are biased against exporters. Hence there is little comfort for the CEE and Baltic producers. However, the EU has made a major concession in this field. Immediately after the signing of the EAs the EU committed itself to treating the countries in question as market rather than non-market economies. This is of prime 
importance as the manner in which antidumping investigations are carried out depend on the type of country concerned. The 'state trading country' arrangements that the EU applied in respect of dumping were replaced on 1 March 1992 by the normal GATT arrangements.

Countervailing duties, which are dealt with in Article 62.3 of the EA with Hungary, can be imposed if they are GATT-consistent. With regard to safeguards, the general safeguard clause in the agreements ties in perfectly with GATT rules. The EU has allowed the CEE and Baltic countries to protect their infant industries during the transition period. Another derogation enables them to deal with balance of payments difficulties. From the point of view of the EU, the agreements allow for unspecified safeguard measures to be taken by the EU. According to Article 30, safeguard measures are permitted if transition-country exports to the EU cause 'serious injury to domestic producers of like or directly competitive products' or 'serious disturbances ... or difficulties which could bring about serious deterioration in the economic situation of a region'. Article 21 is a special safeguard provision for agricultural goods, allowing discretionary contingent protection when imports originating in one country cause serious disturbance to the markets in another country. Bilateral consultation procedures are provided for in the agreements in the context of the anti-dumping and safeguard measures, and greater importance is attached to consultation and conciliation than to unilateral action.

Regarding the movement of workers, companies and services, the agreements do not guarantee access by CEE or Baltic workers to the EU labour market beyond what is guaranteed bilaterally by the member states. They guarantee workers nondiscrimination and certain rights in the EU as long as they are 'legally employed'. In general each party agrees to give the other's enterprises the same treatment as its own. With the EAs came free engagement in foreign direct investment. The EU has granted free entry and national treatment to all CEE and Baltic firms. In the case of Hungarian agreement, Hungary committed itself to grant to EU companies, five years after the entry into force of the agreement, a treatment as favourable as to its own companies. Hungary has granted this treatment within ten years for financial services, acquisition, use and rent of state-owned assets undergoing privatisation and dealing and agency activities in real property and natural resources. Exceptions to this were air transport services, inland water transport services and maritime cabotage. The parties also agreed to take the necessary steps to liberalise trade in services. The temporary movement of persons is permitted. In the case of Hungary, economic cooperation under the EA is aimed at the development of the transport sector, banking, insurance, financial services, telecommunications, postal services and broadcasting. Finally, the EAs require free mobility of capital, full convertibility and the liberalisation of capital account transactions. They authorise any payments on the current account of balance of payments with full convertibility. The parties have to ensure the free movement of capital relating to direct investment and the liquidation and 
repatriation of these investments and any profits. The parties may not introduce any new foreign exchange restrictions.

\section{The effects of the Turkey-EU customs union and the Europe Agreements}

Turkey, by virtue of signing the CUD, and the CEE and Baltic countries by signing the EAs, agreed to undertake major tasks, including the harmonisation of commercial legislation as regards competition policy, state aid, intellectual and industrial property rights, and new rules on customs classification, valuation, rules of origin, technical regulations, standards and government procurement. Since the new rules and regulations were expected to affect the functioning of the markets in the countries concerned, this section will concentrate on what these rules and regulations entailed.

We shall first consider competition policy within the framework of the Turkish economy. During the 1980s and 1990s Turkey used three industrial policy tools: investment incentives, export incentives and policy on stateowned enterprises. In each case the government tried to encourage the desired allocation of resources through the use of subsidies. In order to promote investment in activities and areas regarded as desirable the government provided a number of incentives, regulated by laws and decrees and directed, as explained in Chapter 6 of this volume, at reducing the cost of investment, reducing the need for external financing and increasing profitability. On the export side, the export incentives provided during the 1980s and 1990s did serve to increase the profitability of export activities. Togan (1994) shows that the average economy-wide export subsidy rate decreased from 32 per cent in 1983 to 13 per cent in 1990 . With regard to the policy on state-owned enterprises, the Turkish state enterprise sector is very large and for a long time the state had a monopoly on tobacco, armaments, railways, air transportation, air- and sea-port administration, post and telecommunication, and sugar production. In the manufacturing sector the state-owned enterprises were predominantly involved in basic metals, chemicals, petrochemicals, fertilisers, newsprint, paper, oil refineries, cement and textile production. In general the state-owned enterprises put in a poor economic performance due to the existence of soft budget constraints. They were not subject to the commercial code and as such escaped the bankruptcy laws. The enterprises received subsidies from the government in the form of direct transfers, equity injections and debt consolidation. There were also barriers to exit.

The aim of the investment incentive schemes in Turkey was to encourage investment and not to increase competition in the country. The credit incentives, which were supposed to promote entry, often served to reinforce the position of large incumbents. Furthermore the government, with its large share of the banking system, directly controlled the allocation of credit, and credit from public banks was often extended on the basis of considerations other than commercial ones. For a long time there was no specific competition legislation or policy. To promote competition within the country, during the 
1980s Turkey eliminated quantitative restrictions on foreign trade and substantially reduced the level of nominal and effective protection rates. But the reduction of these rates was not sufficient to ensure proper functioning of the markets. Recognising the need for a competition policy Turkey adopted the Law on the Protection of Competition in December 1994.

Regarding the export regime, Turkey joined the GATT Subsidies Code in 1985 and agreed to eliminate export subsidies by 1989. Since Turkey is a member of the World Trade Organisation it accepted the 1994 GATT Agreement on Subsidies and Countervailing Measures (SCM), which prohibits member governments from granting subsidies contingent upon either export performance or the use of domestic products. Accordingly Turkey withdrew most of its investment and export incentives. In this context, GATT-permitted subsidies such as research and development subsidies and subsidies to facilitate the adaptation of plants to new environmental regulations were introduced in 1995. Export subsidies would be restricted to R\&D activities and environmental projects, and financial assistance to export promotion activities directed at participation in trade fairs, the contracting of market research and the organisation of educational activities such as seminars and conferences.

Although considerable progress has been achieved in the area of investment and export incentives, the same cannot be said of public enterprises. While privatisation has been a prominent part of the Turkish structural adjustment programme since 1983 it has not gained momentum because various difficulties have been encountered.

The CUD decreed that all agreements between enterprises that would restrict or distort competition, any abuse by an enterprise of a dominant position and any public aid that served to distort competition were incompatible with the functioning of the customs union. It was agreed that state monopolies of a commercial character would be adjusted between the third and fifth years. Furthermore Turkey was required to ensure that no measures taken for public enterprises and enterprises with special or exclusive rights should disturb trade between the two parties, and to remove exit and entry barriers through the application of competition rules. Finally, in order to comply with the rules of the CUD Turkey was required to stop subsidising its public enterprises at the prevailing rates, align its state aid policies with those of the EU and apply the same competition policies to all firms, both private and public. This adjustment would certainly be costly, but unless the system of state aid was aligned to those in the EU, and unless competition rules were applied effectively to all private and public firms, the EU could use commercial defence instruments (antidumping and countervailing duties) against Turkey.

The CU rules on subsidies would certainly increase competition in Turkey. When faced with intensified competition, domestic industries, which may have reaped monopoly and oligopoly profits in a relatively protected domestic market, would be forced to behave competitively. The concentration ratios in 
Turkey, which were relatively high, were expected to decline over time. Furthermore the price-marginal cost markups would also decline in the private sector after the implementation of competition policies. Public sector firms, for which the profit-maximising framework was inappropriate, were expected to behave more competitively in the future.

Similar considerations apply in the case of the EAs. With regard to the EA signed between Hungary and the EU, the competition provisions are covered in Articles 62-7. Articles 62.1, 62.2, 62.4 (a) and 64 read as follows:

62.1: The following are incompatible with the proper functioning of the Agreement, in so far as they may affect trade between the Community and Hungary: (i) all agreements between undertakings, agreements by associations of undertakings and concerted practices between undertakings which have as their object or effect the prevention, restriction or distortion of competition; (ii) abuse by one or more undertakings of a dominant position in the territories of the Community or of Hungary as a whole or in substantial part thereof; (iii) any public aid which distorts or threatens to distort competition by favouring certain undertakings or the production of certain goods.

62.2: Any practices contrary to this Article shall be assessed on the basis of criteria arising from the application of the rules of Articles 85, 86 and 92 of the Treaty establishing European Economic Community.

62.4 (a): For the purposes of applying the provisions of paragraph 1 (iii), the Parties recognise that during the first five years after the entry into force of this Agreement, any public aid granted by Hungary shall be assessed taking into account the fact that Hungary shall be regarded as an area identical to those areas of the Community described in Article 92 (3) of the Treaty establishing the European Economic Community. The Association Council shall, taking into account the economic situation of Hungary, decide whether that period should be extended by further period of five years.

64: With regard to public undertakings, and undertakings to which special or exclusive rights have been granted, the Association Council shall ensure that as from the third year following the date of entry into force of this Agreement, the principles of the Treaty establishing the European Economic Community, in particular Article 90, and the principles of the concluding document of the April 1990 Bonn meeting of the Conference on Security and Co-operation in Europe, in particular entrepreneurs' freedom of decision, are upheld.

Thus the EA rules on competition relate to agreements between firms that restrict competition, the abuse of dominant power, the behaviour of public 
undertakings and competition-distorting state aid. The rules are concerned with the behaviour of governments as well as firms. According to Article 62.5 the provisions of Article 64.1 do not apply to agricultural, fishing, coal and steel products. Article 62.4 (a) states that state aid, compatible with EU rules for disadvantaged regions (Article 92.3 (a) of the Treaty of Rome), can be applied to entire territories during the first five years. In the case of Hungary, any public aid granted within the first five years had to be assessed. Furthermore, all parties must ensure transparency in the area of public aid. Since the EA competition rules are similar to those specified in Articles 30.1, 31.1, 32.1 and 33 of the Turkey-EU CUD, considerations similar to those outlined in the case of Turkey will apply. In the meantime all the CEE and Baltic countries have introduced competition legislation, modelled on the EU approach to competition policy.

The success of the transition from the situation where antidumping measures are used, as in the case of Turkey-EU and CEE-EU trade, to the situation where commercial relations are governed by competition rules will depend on the level of integration between the states. This integration will be accelerated, as stressed by Marceu (1995), if markets are harmonised through stronger competition enforcement and the phasing out of antidumping measures. Thus success depends on the effective implementation of competition policies by the governments of Turkey and the CEE and Baltic countries.

Besides competition policies the CUD has clauses on intellectual, industrial and commercial property rights. The CUD required Turkey to accede by 1 January 1996 to the Stockholm Act of the Paris convention on the protection of industrial property, the Patent Co-operation Treaty, the Nice Convention on the international classification of goods and services for the purposes of registering marks, the Paris Act of the Bern convention on the protection of literary and artistic works, and the Rome convention on the protection of performers, producers of phonograms and broadcasting organisations. In addition Turkey was required adopt EU legislation in respect of industrial property, copyright and neighbouring rights, and to ensure adequate and effective protection and enforcement of intellectual property rights. It was obliged to implement the GATT Uruguay Round decision on Trade Related Aspects of Intellectual Property Rights (TRIPS) by 1999. Furthermore, by 1 January 1998 it was expected to pass legislation to secure the patentability of pharmaceutical products and processes. With regard to copyright, the CUD required that counterfeiting or bootlegging be effectively banned and that protection in the case of translation should not be less than fifty years when the term is calculated on a basis other than the life of the person. By 1999 Turkey had to accede to the Protocol of the Madrid agreement on the international registration of marks, the Budapest treaty on international recognition of micro-organisms for the purposes of patenting and the international convention on the protection of new varieties of plants. Finally, by 1 January 1996 Turkey had to implement the EU regulation on the prohibition of counterfeit goods (EEC 3077/87). Turkey now has new 
copyright and patent laws that conform with the EU conditions and a Patent Office to help with the implementation of these laws.

Similar considerations apply to the EAs. Articles $63-4$ of the EA with Hungary required Hungary, within five years, to provide a similar level of protection of intellectual, industrial and commercial property rights to those existing in the EU, including comparable means of enforcing such rights. At the end of the fifth year Hungary had to comply with the Munich Convention, the protocol relating to the Madrid agreement on the international registration of marks and the international convention on the protection of performers, producers of phonograms and broadcasting organisations.

As is well known, the economic rationale for the protection of intellectual property rights is framed in terms of costs and benefits (Hoekman, 1995). The costs include increases in payments for propriety knowledge, price increases associated with greater market power for knowledge producers, the costs of terminating pirate activities, the costs of additional $R \& D$ and the costs associated with the administration and enforcement of intellectual property rights protection. Potential benefits include new inventions fostered by higher levels of $R \& D$, improved technology, increased foreign trade and increased foreign direct investment flows, and hence increases in per capita income. Within this context the main task facing Turkey and the transitional economies is the transformation of their intellectual property rights regime into effective instruments for the promotion of innovation.

In the case of standards, the parties to the CUD stress the importance of effective cooperation in standardisation, testing and certification. The EU will assess the conformity of Turkish industrial products with its own legal requirements. The industrial standards in the EAs involve economic cooperation. The aim is to reduce the differences in standardisation and conformity assessment. The cooperation seeks to promote the use of EU technical regulations and support in the EU measurement and testing programmes.

The CUD recognises the importance of public procurement but does not specify any particular arrangements. On the other hand the EAs give consideration to the awarding of public contracts, in accordance with the GATT rules. Article 26 of the CUD requires Turkey to adopt the EU's customs provisions on the origin of goods, the customs value of goods, the introduction of goods into the territory of the customs union, customs declarations, release for free circulation, the movement of goods, customs debt and right of appeal. Furthermore, for the effective functioning of the customs union the customs system in Turkey had to be modernised. A new draft customs law has been prepared with the aim of speedier customs release, simplified procedures and the full automation of customs procedures, and customs administrative personnel have taken part in extensive training programmes. The Turkish customs will start to make use of a computer system and will introduce an on-line declaration system. Computerisation will make it possible to have at each customs post not only relevant information on the 
collection of customs duties but also information on the preferential trade agreements and antidumping regulations that will be required to determine the correct amount of duties to be collected.

The above considerations suggest that the new rules and disciplines imposed by the CUD and EAs will improve the functioning of markets in the economies under consideration. During the transition period, until about 2002, each of the economies can be considered as moving from an inefficient production point within the production possibility frontier (PPF) towards an efficient production point on the PPF. Furthermore, over time the new rules and disciplines, such as the rules on intellectual property rights, will shift the PPF outward as technical progress is achieved.

We now turn to a consideration of the effect of tariff changes on resource allocation. As nominal protection rates change domestic prices will change, leading to movement along the production possibility frontier of the economy. Among the sectors there will be winners and losers, and in order to identify these we determine the effective protection rates (EPR) for the years 1994 and 2001 and subtract from the value of the EPR for 2001 the value of the EPR for 1994. The results indicate that the customs union will lead to an increase in value added of the sectors grain mill products, sugar refining and clothing, and to a decrease in value added of the sectors processed tobacco, petroleum refining and non-alcoholic beverages. The analysis further reveals that the ten most sensitive sectors in the Turkish economy are processed tobacco, petroleum refining, non-alcoholic beverages, alcoholic beverages, wood furniture, footwear, plastic products, cement, motor vehicles and wood products.

Finally in this section we consider potential trade arrangements in Europe. The EU-15 form a single market, achieved through the Single European Act of 1992. The EFTA countries, except Switzerland, have close ties with the EU through the Agreement on the European Economic Area. The EAs and the Turkey-EU CUD will result in freedom of movement for industrial goods over an expanded area. It is thought that all EFTA countries and all nations with EAs will eventually join the EU, and indeed all countries with EAs have submitted membership applications. At the Cannes meeting in 1995 it was decided to conclude FTAs with the Mediterranean countries with the exception of Libya. By 2001 Turkey will have fulfilled all the requirements of the customs union. If all goes well Russia, Ukraine, Belarus and Moldova will conclude FTAs with the $\mathrm{EU}$ in the not too distant future, and all the other former Soviet countries will have separate agreements on partnership and cooperation with the EU. Freedom of movement of industrial goods among these countries can be achieved if each of the countries signs an FTA not only with the EU but also with each other. This objective has been partially achieved through the Central European Free Trade Agreement and the Baltic Free Trade Agreement. Turkey has recently signed FTAs with Israel and Hungary and is expected to sign FTAs with the Czech Republic, Lithuania, Poland, Romania and the Slovak Republic. Once the CEE, Baltic and Mediterranean countries, together 
with Russia, Ukraine and Belarus, have concluded FTAs among themselves, European free trade and investment opportunities will extend over a large region from Morocco to Siberia and from Finland to Turkey.

\subsection{Potential for trade between the EU, CEE and Baltic countries and Turkey}

As the CEE and Baltic countries complete their transition to market economies and enjoy increased access to EU markets the geographical distribution of trade will change. A critical question is: what is the potential for trade between the EU, CEE and Baltic countries and Turkey. This question has been addressed by various economists, including Winters and Wang (1994) and Baldwin (1994). They show that potential trade with the EU is much larger than actual trade. Thus when the CEE and Baltic countries have completed their transition, are integrated into the world trading system and have full access to EU markets through the EAs and FTAs their trade with the EU countries will increase.

To estimate Turkey's potential trade with the transitional economies we consider following Baldwin (1994), the gravity model of Bergstrandt (1985). According to this model a country's total imports increase with per capita income and size of population. Thus the country tends to import more with increases in its per capita income, the per capita income of the partner country and the size of both populations. Finally, distance dampens trade since it is generally more convenient and cheaper to buy from nearby countries. Using bilateral trade data for 20 industrial countries over the period 1990-94, consisting of 2000 observations, we estimate the coefficients in the following equation:

$$
\begin{aligned}
1 n X_{a b}= & \alpha+\alpha_{I} 1 n\left(G N P_{a} / P O P_{a}\right)+\alpha_{2} 1 n\left(G N P_{b} / P O P_{b}\right)+\alpha_{3} 1 n P O P_{a} \\
& +\alpha_{4} 1 n P O P_{b}+\alpha_{5} 1 n D I S T_{a b}
\end{aligned}
$$

Where $X_{a b}$ denotes the exports of country $a$ to country $b, G N P_{a}$ the income of country $a, G N P_{b}$ the income of country $b, P O P_{a}$ the population of country $a$, $P O P_{b}$ the population of country $b, D I S T_{a b}$ the distance between countries $a$ and $b$, and $1 n$ the natural logarithm. The coefficients are given by:

$$
\begin{aligned}
& 1 n X_{a b}=-26.16+0.993441 n\left(G N P_{a} / P O P_{a}\right)+0.41221 n \\
& (-49.41) \quad(43.314) \\
& \left(G N P_{b} / P O P_{b}\right)-\underset{(-63.754)}{0.8472} 1 n D_{I S T_{a b}}+\underbrace{0.8137}_{(56.997)} 1 n P^{\prime} P_{a}+
\end{aligned}
$$

$0.8151 n \mathrm{POP}_{b}$

(66.344) 


$$
n=2000, \mathrm{R}^{2}=0.879 ; \rho=0.1636 ; \mathrm{DW}=2.055
$$

The GNP and population data were obtained from a World Bank CD-Rom (1995) and the bilateral trade flow data from IMF (1995) converted to real trade data using the trade prices reported in World Economic Outlook (IMF, October 1996). Distance refers to kilometre road distances between capital cities. For countries separated by water, sea distances have been converted to road distance equivalents. The equation, estimated for the period 1990-94, shows that bilateral trade flows are increasing in terms of per capita income and populations and decreasing in distance.

The gravity model, which was estimated on data that does not include the CEE and Baltic countries and Turkey, gives a relationship between GNP, distance and bilateral trade flows for a 'normal' country, that is, one that is integrated into the world trade system as the average of the industrial countries sample. A 'normal' country is supposed to face no restrictions on market access. With this equation estimated we can now predict the trade flows between Turkey and the transitional economies once the latter become 'normal' countries; that is, when they have completed their transition and become market economies, are integrated into the world trading system and face no major market access problems. The mechanics of the projection are simple. Estimates for the relevant countries' per capita GNP, population and distance are plugged into the equation, which generates the import and export pattern for trade between the countries in question.

Table 2.12 shows the potential value of exports and imports for trade between Turkey and the CEE and Baltic countries in 1995 and 2005. It is clear from the table that potential trade is much larger than actual trade. The data reveal that Turkey's potential exports to the transitional economies in 1995 amounted to about 269 per cent more than actual exports and that imports from these countries could increase by 300 per cent. Projections for the year 2005 reveal that given normal circumstances Turkey's trade with these countries will increase considerably over the coming decades.

\subsection{The chances of EU membership}

To study Turkey's and the transition countries' chances of EU membership we shall consider the evidence on previous enlargements, as reported in Table 2.13. Accession to the EU is heavily dependent on the existence of democracy in the applicant country, the level of per capita income, the size of the population and the share of the agricultural sector. In a number of earlier cases (Greece, Spain and Portugal) the applicant country had to prove that democracy had been fully restored. In previous enlargements the successful applicants had a per capita income which was at least as large as 61.4 per cent of the poorest EC member, a population that was smaller than 26.9 per cent of 


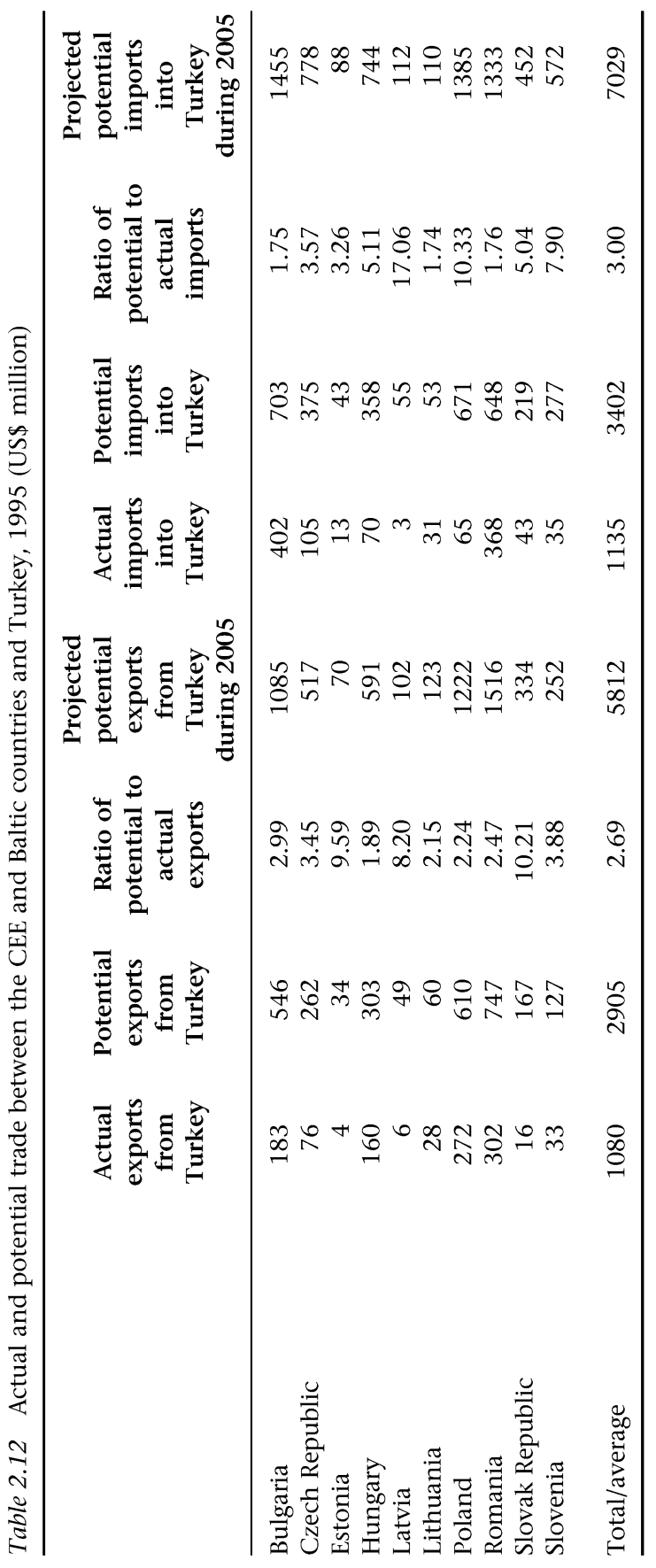



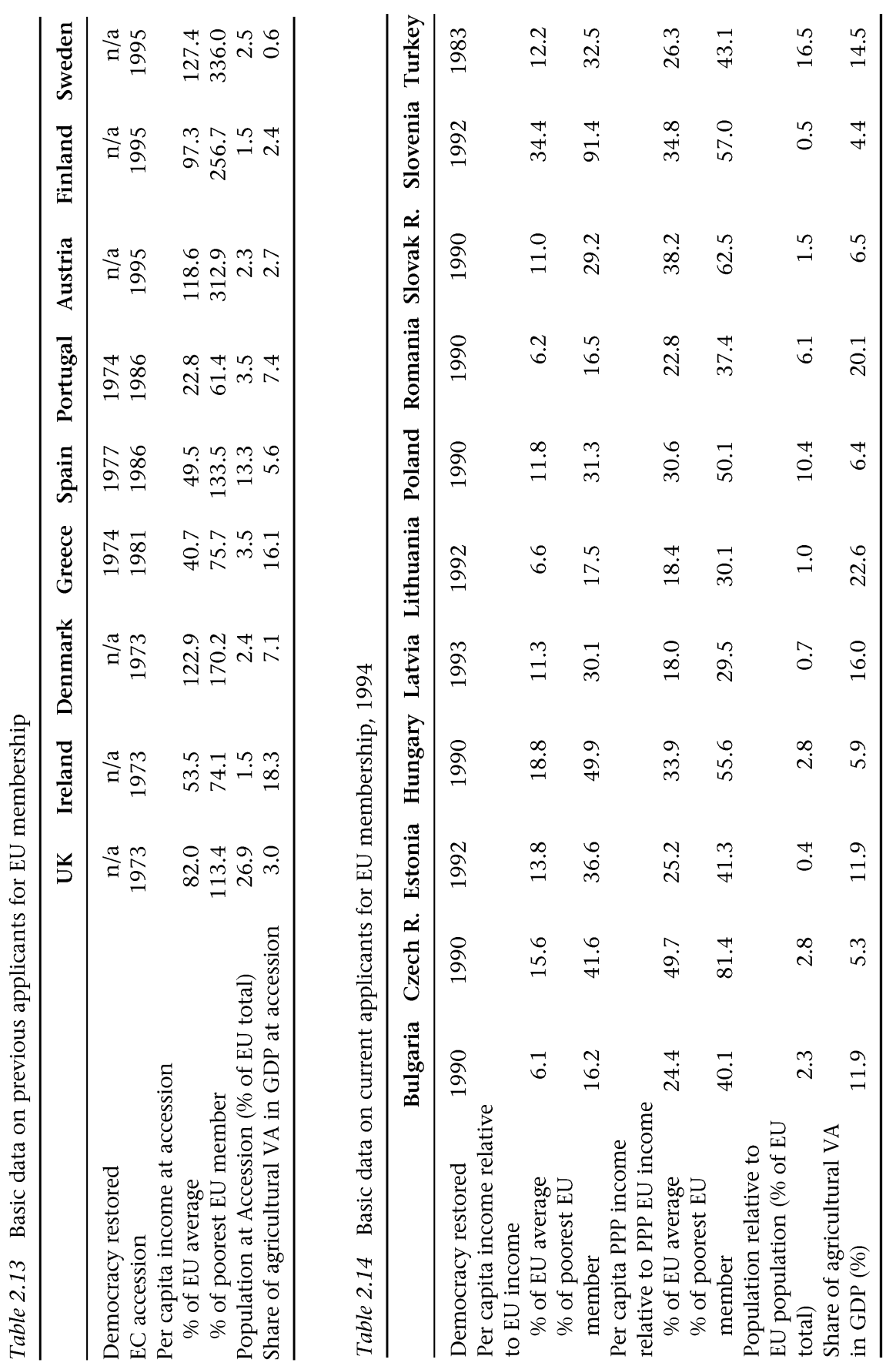
EC population at the time of the accession, and a share of agriculture which was not larger than 18.3 per cent of GDP. Table 2.14 gives similar data on the transitional economies and Turkey. Democracy was restored in the transitional economies during the 1990s. Turkey, on the other hand, has had an open and liberal political system since 1983 . With regard to population, the EU population would increase by 16.5 per cent if Turkey were granted membership and by 29 per cent following the accession of the transitional economies. In 1994 the share of agriculture in GDP was 22.6 per cent in Lithuania, 20.1 per cent in Romania, 16 per cent in Latvia, 14.5 per cent in Turkey, 11.9 per cent in Bulgaria and 11.9 per cent in Estonia. PPP per capita income in Latvia was 29.5 per cent that of Greece, in Lithuania it was 30.1 per cent, in Romania 37.4 per cent, in Bulgaria, 40.1 per cent, in Estonia 41.3 per cent, in Turkey 43.1 per cent and in the Czech Republic 81.4 per cent. Thus based on the 1994 figures of the countries considered only the Czech Republic and the Slovak Republic would satisfy the 61.4 per cent criterion

Given the per capita income levels reported in Table 2.1 we shall now consider how incomes will change over time, and whether the CEE and Baltic countries and Turkey will be able to catch up with the 61.4 per cent per capita income level of the poorest EU member in the near future. Table 2.15, which is based on PPP estimates of per capita incomes, reveals the following:

- If the transitional economies' GNPs were to grow at the pessimistic rate of 3 per cent and Turkey's GNP at the rate of 4.4 per cent all the countries but Romania, Latvia, Lithuania and Turkey would reach 61.4 per cent of Greek per capita income in 25 years.

- If transitional economies' GNPs were to grow at the more probable rate of 5 per cent and Turkey's at 5.4 per cent, Hungary and Poland would reach the 61.4 per cent Greek per capita income level in five and ten years respectively. The 61.4 per cent criterion would not be satisfied by Latvia, Lithuania and Turkey. After 25 years Turkey's per capita income would amount to 57 per cent, Lithuania's 53.8 per cent and Latvia's 58.2 per cent of the Greek level.

- If the transitional economies' GNPs were to grow at the rate of 6 per cent and Turkey's at 7 per cent, Turkey would satisfy the condition in 15 years, and Lithuania and Latvia after 20 years.

Thus the projections reveal that if these countries' GNPs grow at the latter, rather optimistic rates then all the applicants, including Turkey, will satisfy the 61.4 per cent criterion in about $15-20$ years.

Baldwin (1994) summarises the conditions for EU membership under eight headings: (1) free movement of goods, services and factors of production within the $\mathrm{EU}$; (2) adoption of the EU common external tariff and trade policy vis-à-vis third countries; (3) harmonisation of commercial legislation; (4) participation in the European Monetary System and single currency; 


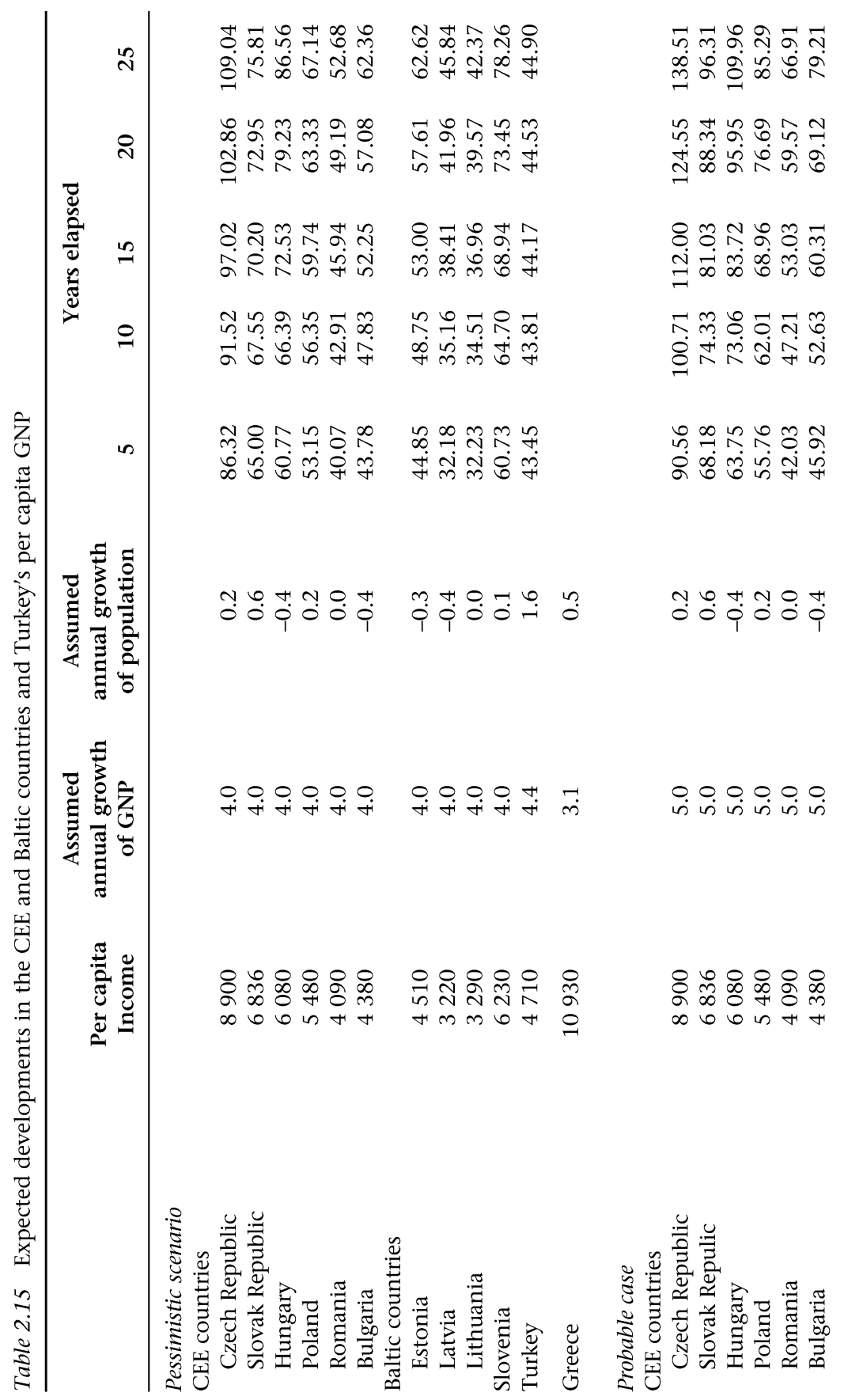




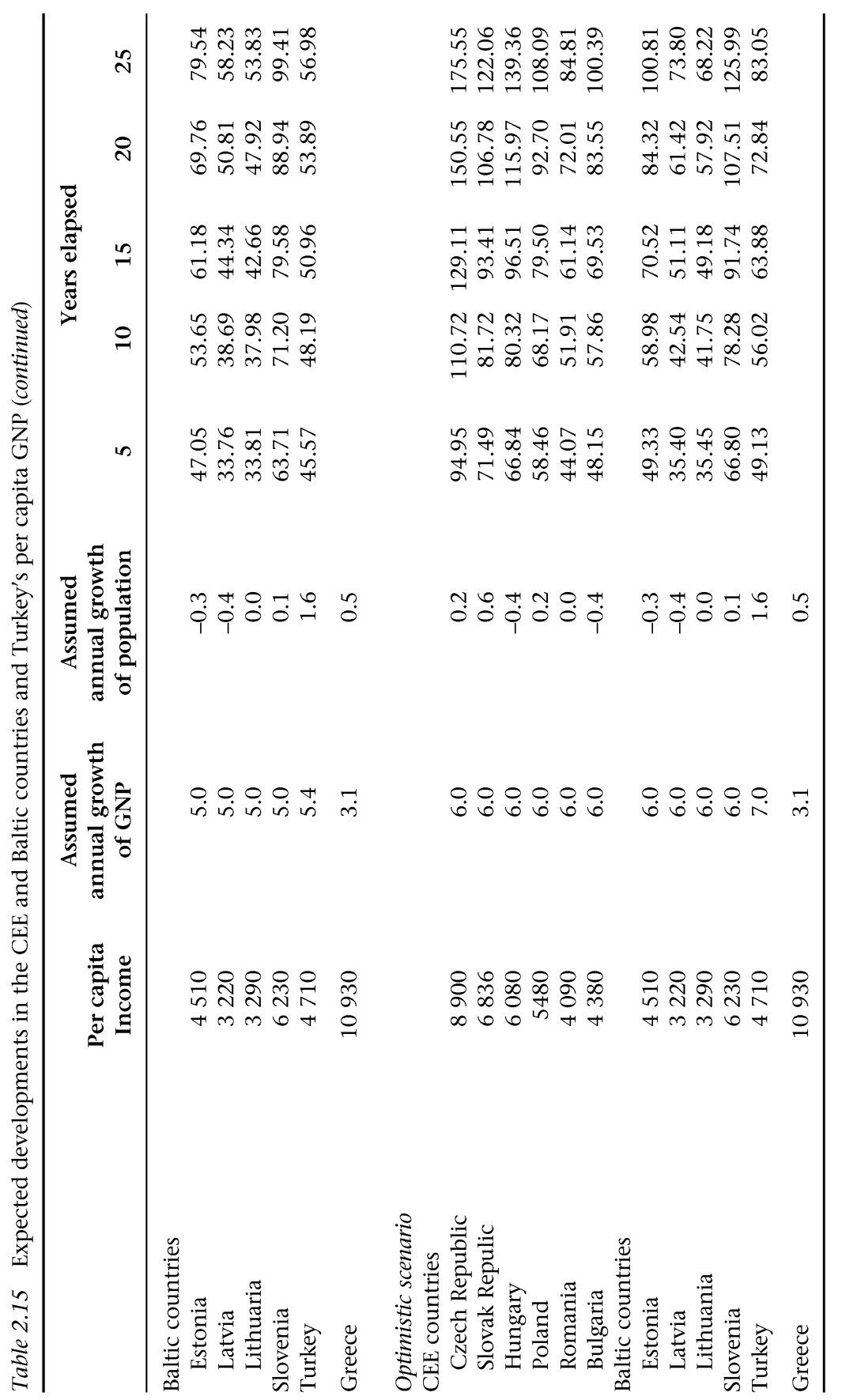


(5) adoption of the EU Common Agricultural Policy; (6) a supranational appellate system to ensure consistent application of EU law throughout the Union; (7) open government procurement; and (8) a common policy promoting disadvantaged regions by structural spending. As emphasised above, Turkey, by forming the $\mathrm{CU}$ with the $\mathrm{EU}$, satisfied the condition of free movement of industrial goods. But free movement of agricultural commodities and services are not covered by the CUD. The CUD is silent on the movement of capital and does not include any provisions on the free movement of labour. Hence the first condition of membership is satisfied partially. Since Turkey has already adopted the EU's common external tariff and will adopt the EU's trade policy vis-à-vis third countries at the latest in 2001 and harmonised its commercial legislation with that of EU, the second and third conditions of membership will completely be satisfied by the year 2001. The fourth condition (participation in EMU) is not a requirement for membership. The CUD considers the fifth condition but it is not likely that Turkey will adopt the CAP in the near future as this would require external assistance. The CEE and Baltic countries will soon be able to satisfy the third condition of membership. The first condition is only partially satisfied as the agreements do not cover the free movement of labour. The EAs contain sections on services and capital movements. Since EAs are free trade agreements the transitional economies do not satisfy the second condition of membership. The countries are free to determine their tariff levels against third countries. Regarding the CAP, similar considerations as in the Turkish case apply to the fifth condition. The fourth condition (participation in EMU) is again not a requirement for membership.

The conditions that are of real concern to the EU are the fifth (the CAP) and the eighth (the structural funds). The net cost to the EU is the important variable as this should not involve more transfers than the richer EU countries can reasonably be expected to finance. To determine the net cost to the EU of accession by the CEE and Baltic countries and Turkey we make use of the results obtained and the approach developed by CEPR (1992) and Baldwin (1994), where net cost is defined as the difference between the sum of the structural funds and the CAP price support received by the countries concerned net of the national budgetary contributions to the EU.

We shall consider the problems associated with the adoption of the CAP using the example of Turkey, where agriculture is of great economic importance - in 1994-95 it accounted for about 14.5 per cent of GDP and 46 per cent of total employment. These shares have been falling over time, but compared with other EU countries they are still relatively high. Value added per agricultural worker in Turkey amounts to only 21 per cent of the value added per non-agricultural worker. The low productivity in agriculture is associated with a farm structure characterised by small, fragmented farms and poor education and training, leading to low farm-household incomes. Furthermore, a large proportion of the Turkish population still live in rural 
areas. Until recently the population growth rates exceeded 2 per cent a year. The highest fertility rates are in rural areas, and emigration from these areas also tends to be high. Although migration abroad has slowed down, internal migration to urban areas continues at a fast pace. The stated objectives of Turkish agricultural policy are to ensure adequate levels of nutrition and food supplies at reasonable prices to consumers, to raise production levels and yields while reducing the vulnerability of production to adverse weather conditions, to raise the level of self-sufficiency, to increase farm incomes and improve their stability, to increase exports and to develop rural areas. In line with these objectives the government has implemented a set of measures based on the support of producer prices and complemented by trade-related measures, the subsidisation of farm inputs and transfers for investment in infrastructural projects. In order to measure the total support provided to agriculture the OECD (1994) calculates producer subsidy equivalents (PSEs), which measure the value of monetary transfers to producers from consumers of agricultural products and taxpayers, resulting from a given set of agricultural policies in a given year. According to the OECD (1994) total support, as measured by the percentage PSE, was around 40 per cent during 1991-93, and the share of total agricultural transfers in total GDP was 13.7 per cent in 1991, 11.5 per cent in 1992 and 11.1 per cent in 1993. At this point it should also be noted that agriculture, besides being subsidised, has also been heavily protected, as one can see from columns 1 and 3 of Table 2.9.

According to Articles 22-5 of the CUD, in order to bring about freedom of movement of agricultural products Turkey will have to align its agricultural policy with the CAP measures. But is this possible? What would the adoption of CAP measures mean for Turkey? At current domestic prices Turkey is a net exporter of some and a net importer of other farm products. But when domestic prices are converted at equilibrium exchange rates they are generally below EU domestic prices. If Turkey were given tariff-free access to EU agricultural markets at existing EU prices then supply could be expected to increase in Turkey. The output of farm products in Turkey would be higher, the aggregate level of food self-sufficiency would rise and Turkish consumers would face higher prices. Faced with similar problems, Anderson and Tyers (1993) estimate that the CAP price support of admitting the Visegrad-4 countries (the Czech Republic, Hungary, Poland and the Slovak Republic) to the EU would amount to ECU 37.6 billion a year. On the other hand a study by the European Commission (1996) reports that the CAP price support of admitting the CEE-10 countries would only amount to ECU 8.96 billion a year. Unfortunately there are no similar studies for the Turkish case. It could be argued that Turkey could support the agricultural sector by establishing a fund similar to the FEOGA and that the amount of support would be similar in magnitude to that of the CEE countries. But who would provide the necessary funds in the Turkish case? Since Turkey cannot devote an amount similar to the figures given above from its own resources, and since the EU would be 
unwilling to bear the cost, the idea of establishing a fund similar to the FEOGA in Turkey has to be abandoned. Consequently it seems that freedom of movement of agricultural products between Turkey and the EU will not be achieved in the near future.

Next we shall consider the structural funds. These are transfers from Brussels to poorer member states and regions to encourage greater economic and social cohesion. About half of the structural funds are channelled into low-income regions, defined as regions with per capita incomes of less than 75 per cent of the EU average. The funds are used to improve infrastructure in the lowincome regions and provide local training. According to Courchene (1993) the Visegrad- 4 would receive ECU 26 billion per annum.

The budget revenues of the EU consist of receipts based on national VAT receipts, tariff revenues, variable duties and GNP contributions. Currently the budget amounts to about 1.3 per cent of the EU's total GDP. Based on this percentage the expected annual contribution of the CEE and Baltic countries is ECU 4 billion.

The above considerations reveal that the net annual cost of admitting the CEE-10 countries to the EU could range between ECU 30.96 billion and ECU 80 billion, depending on the estimates one uses. Baldwin (1994), on the other hand, estimates the net annual cost as ECU 26.7 billion. All of the estimates are rather rough, but one thing is clear: a large burden would be imposed on EU taxpayers if the transitional economies entered now and the EU applied its current rules on CAP and structural funds. If the EU intends to admit these countries then either the EU budget has to be increased considerably or the rules on the structural funds and price support under the CAP have to change.

Since there are no quantitative studies on the net costs of Turkish membership similar figures cannot be given in the case of Turkey, but it is clear that the net cost to the EU of admitting Turkey would fall substantially if the current rules on the structural funds and price support under CAP were changed.

From the point of view of Turkey, EU membership is desirable as the EU is and will continue to be a major trading partner, and it is likely to be the major source of technology and investment for Turkey in the coming decades. As an economic integration model, membership of the $\mathrm{EU}$ is the best option. It would mean recognition of Turkey as part of Europe. It would lock in Turkey's political and economic reforms and provide the reforms with credibility. And it would mean increased competition for Turkey within the European free trade and investment area, leading to improved allocation of resources and hence increases in per capita income.

From the point of view of the EU there are economic as well as political gains to be derived from Turkish membership. Turkey is a large and rapidly expanding market. It is in fact the largest market in the Middle East, Balkans and Caucasus. According to the World Bank (1996) Turkish GDP is as much as 35 per cent of the Russian GDP. Located at the crossroads of Europe, Eurasia 
and the Middle East, Turkey has the potential to act as a major link between these markets. Since the implementation of the CU Turkey has been harmonising its commercial legislation with that of the EU, and EU companies will be able to use Turkey as a joint investment and export base for the Middle East and Eurasia. Istanbul is already emerging as the home of transnational headquarters for operations in the Caucasus and Central Asia. As incomes in Turkey, the Balkans and Eurasia increase the EU will derive gains from increased trade. Likewise trade between Turkey and the Mediterranean, CEE10 and Eurasian countries will expand as European trade and investment opportunities extend over this region. There will be budgetary costs to the EU of Turkish membership, but these costs will decrease with changes to the rules on the structural funds and price support under the CAP. In any case the EU's budgetary outlays have to be evaluated in relation to the potential gains to be had from increased trade and political stability. By securing stability and security in the Balkans and Caucasus the EU could increase its energy security and decrease its defence expenditure from the present 2.5 per cent of EU GDP. Turkish accession thus offers the prospect of economic growth in the EU. High and sustainable GNP growth is a prerequisite for membership of the EU. But the whole question of enlargement boils down to how much the EU is willing to spend on integrating new members. 


\section{Appendix 2.1 SITC classification scheme, revision 2}

\begin{tabular}{|c|c|c|c|}
\hline SITC & Commodity & SITC & Commodity \\
\hline & Food and live animals chiefly for food & & Manufactured goods classified chiefly by material \\
\hline 00 & Live-animals chiefly for food & 61 & Leather manufactures \\
\hline 01 & Meat and meat preparations & 62 & Rubber manufactures \\
\hline 02 & Dairy products & 63 & Cork and wood manufactures \\
\hline 03 & Fish and fish preparations & 64 & Paper \\
\hline 04 & Cereals and cereal preparations & 65 & Textiles \\
\hline 05 & Vegetables and fruit & 66 & Non-metallic mineral manufactures \\
\hline 06 & Sugar and sugar preparations & 67 & Iron and steel \\
\hline 07 & Coffee, tea, cocoa, spices & 68 & Non-ferrous metals \\
\hline 08 & Feeding stuff for animals & 69 & Manufactures of metal \\
\hline \multirow[t]{3}{*}{09} & Miscellaneous edible products & & \\
\hline & & & Machinery and transport equipment \\
\hline & Beverages and tobacco & 71 & Power generating machinery and equipment \\
\hline 11 & Beverages & 72 & Machinery specialised for particular industries \\
\hline \multirow[t]{3}{*}{12} & Tobacco and tobacco manufactures & 73 & Metalworking machinery \\
\hline & & 74 & General industrial machinery and equipment \\
\hline & Crude materials, inedible, except fuel & 75 & Office machines \\
\hline 21 & Hides, skins and furskins & 76 & Telecommunications apparatus \\
\hline 22 & Oil seeds and oleaginous fruit & 77 & Electrical machinery \\
\hline 23 & Crude rubber & 78 & Road vehicles \\
\hline 24 & Cork and wood & 79 & Other Transport equipment \\
\hline 25 & Pulp and waste paper & & \\
\hline 26 & Textile fibres andwaste & & Miscellaneous manufactured articles \\
\hline 27 & Crude fertilisers and crude minerals & 81 & Sanitary, plumbing, heating \\
\hline 28 & Metalliferrous ores and metal scrap & 82 & Furniture \\
\hline \multirow[t]{4}{*}{29} & Crude animal and vegetable materials & 83 & Travel goods \\
\hline & & 84 & Clothing \\
\hline & Mineral fuels, lubricants and related & 85 & Footwear \\
\hline & materials & 87 & Scientific instruments and optical goods \\
\hline 32 & Coal & 88 & Photographic apparatus and optical goods \\
\hline 33 & Petroleum and petroleum products & 89 & Miscellaneous manufactured articles \\
\hline 34 & Gas, natural and manufactured & & \\
\hline \multirow[t]{2}{*}{35} & Electric current & & $\begin{array}{l}\text { Commodities and transactions not classified } \\
\text { elsewhere }\end{array}$ \\
\hline & $\begin{array}{l}\text { Animal and vegetable oils, fats and } \\
\text { waxes }\end{array}$ & 91 & Postal packages \\
\hline 41 & Animals oils and fats & 93 & Special transactions \\
\hline 42 & Fixed vegetable oils and fats & 94 & Animals, live \\
\hline \multirow[t]{3}{*}{43} & Animal and vegetable oils and fats & 95 & Armored fighting vehicles \\
\hline & & 96 & Coin \\
\hline & Chemical and related products & 97 & Gold, non-monetary \\
\hline 51 & Organic chemicals & & \\
\hline 52 & Inorganic chemicals & & \\
\hline 53 & Dyeing, tanning and colouring materi & & \\
\hline 54 & Medicinal and pharmaceutical produc & & \\
\hline 55 & Essential oils and perfume materials & & \\
\hline 56 & Fertilisers, manufactured & & \\
\hline 57 & Explosives & & \\
\hline 58 & Plastic materials & & \\
\hline 59 & Chemical materials and products, NES & & \\
\hline
\end{tabular}




\section{Note}

1. I am grateful to Bernard M. Hoekman for comments on an earlier draft of this chapter. All errors are of course mine.

\section{References}

Anderson, K. and R. Tyers (1993) 'Implications of EC Expansion for European Agricultural Polices, Trade and Welfare', Centre for Economic Policy Research Discussion Paper Series no. 829 (London: Centre for Economic Policy Research).

Baldwin, R. E. (1994) Towards an Integrated Europe (London: Centre for Economic Policy Research).

Bergstrandt, J. H. (1985) 'The Gravity Equation in International Trade: Some Microeconomics Foundations and Empirical Evidence', Review of Economic Studies, pp. $474-8$.

Centre for Economic Policy Research (CEPR) (1992) Is Bigger Better? The Economics of EC Enlargement (London: Centre for Economic Policy Research).

Commission of the European Communities (1991) The Community Budget: The Facts in Figures, Centre for Economic Policy Research: Third Edition, Situation 1990 (Brussels: Office for Official Publications of the European Communities).

Commission of the European Communities (various years) statistics provided on Diskettes (Luxembourg: Statistical Office, trade European Commission).

Commission of the European Communities (1996) 'The CAP and Enlargement', European Economy, Reports and Studies, no. 2.

Courchene, T., C. Goodhart, A. Majocchi, W. Moesen, T. Prud'homme, F. Schneider, S. Smith, B. Spahn and C. Walsh (1993) 'Stable Money - Sound Finances: Community Public Finance in the Perspective of EMU', European Economy, No. 53.

Economist Intelligence Unit Country reports and country profiles on the CEE countries, Baltic countries and Former Yugoslavia (London: Economist Intelligence Unit).

European Bank for Reconstruction and Development (EBRD) (1994) Transition Report (London: European Bank for Reconstruction and Development).

European Bank for Reconstruction and Development (EBRD) (1996) Transition Report (London: European Bank for Reconstruction and Development).

General Agreement on Tariffs and Trade (GATT) (1993) Trade Policy Review European Union 1993 (Geneva: General Agreement on Tariffs and Trade).

Hoekman, B. M. and P. C. Mavroidis (1994) 'Linking Competition and Trade Policies in Central and Eastern European Countries', World Bank Policy Research Working Paper 1346 (Washington, DC: World Bank).

Hoekman, B. M. (1995) 'Trade Laws and Institutions: Good Practices and the World Trade Organization', World Bank Discussion Paper 282 (Washington, DC: World Bank).

International Monetary Fund (IMF) (1995) Direction of Trade Statistics Yearbook (Washington, DC: International Monetary Fund).

International Monetary Fund (IMF) (1996) World Economic Outlook October 1996 (Washington, DC: International Monetary Fund).

Kaminski, B. (1994) "The Significance of the "Europe Agreements" for Central European Industrial Exports', World Bank Policy Research Paper 1314 (Washington, DC: World Bank).

Kirmani, N., N. Calika, R. Harmsen, M. Leidly, A. Subramanian, and P. Uimonen (1994) International Trade Policies: The Uruguay Round and Beyond: Volume I. Principal Issues (Washington, DC: International Monetary Fund). 
Laird, S. and A. Yeats (1990) Quantitative Methods for Trade Barrier Analysis (London: Macmillan).

Marceu, G. (1995) 'The Full Potential of the Europe Agreements: Trade and Competition Issues: The Case of Poland', World Competition, pp. 35-69.

Mastropasqua, C. and V. Rolli (1994) 'Industrial Countries' Protectionism with Respect to Eastern Europe: The Impact of the Association Decisions Concluded with the EC on the Exports of Poland, Czech Republic and Hungary', World Economy, Vol. 17, no. 2, pp. 151-69.

Organisation for Economic Co-operation and Development (OECD) (1992) Economic Surveys. Turkey 1991-1992 (Paris: Organisation for Economic Co-operation and Development).

Organisation for Economic Co-operation and Development (OECD) (1994) National Policies and Agricultural Trade: Country Study Turkey (Paris: Organisation for Economic Co-operation and Development).

Togan, S. (1994) Foreign Trade Regime and Trade Liberalisation in Turkey during 1980s (London: Avebury).

Togan, S. (1995) 'Turkey and European Union' in H. Ersel (ed.), Towards a New Medium Term Stabilization Program for Turkey, Turkish Industrialists and Businessmen's Association, publication no. TUSIAD-T/95, 6-180 (Istanbul).

Vienna Institute for Comparative Economic Studies (WIIW) (1996), WIIW Handbook of Statistics Countries in Transition 1996 (Vienna: Vienna Institute for Comparative Economic Studies).

Winters, L. A. and Z. K. Wang (1994) Eastern Europe's International Trade (Manchester and New York: Manchester University Press).

World Bank (1995) World Development Report 1995 (Washington, DC: World Bank). World Bank (1996) World Development Report 1996 (Washington, DC: World Bank). 